\title{
21. AN INTERPRETATION OF THE GEOLOGIC HISTORY OF THE EASTERN EQUATORIAL PACIFIC FROM THE DRILLING RESULTS OF GLOMAR CHALLENGER, LEG $9^{1}$
}

\author{
James D. Hays, Harry Cook, Graham Jenkins, William Orr, Robert Goll, \\ Frances Cook, Dean Milow, John Fuller
}

The site reports of this volume have presented the details of our findings at each site drilled. Separate synthesis chapters are presented which summarize various aspects of the sediments that were recovered. The purpose of this chapter is to combine information from all sites and to report our findings as they relate to specific problems that were raised in the Introduction to this volume.

These problems can be divided into two categories: those dealing with tectonics of the area (latitudinal and longitudinal) movements of the Pacific plate, and problems that relate to the sediments such as their cyclicity and the nature of the basement sediment contact.

\section{TECTONIC CONSIDERATIONS}

\section{Motion of the Pacific Plate}

As mentioned in the Introduction to this volume although numerous studies of magnetic anomaly patterns in the Pacific have been made (Vine, 1966; McKenzie and Parker, 1967; Pitman and others, 1968; Herron and Hayes, 1969; Atwater and Menard, 1970; Atwater, 1970; Hayes and Pitman, 1970 and more recently Herron, in press), the analyses of the anomaly pattern of the equatorial Pacific have been limited because magnetic anomalies associated with northerly trending ridges near the equator have low amplitudes and are difficult to interpret. Consequently, very little has been published on the development of the Central Pacific some 20 degrees on either side of the equator.

The difficulty of using magnetic anomaly data in this region makes the drilling results of Leg 9 critical to an understanding of the evolution of the eastern Equatorial Pacific.

\section{Longitudinal Motion of the Plate}

All of the eight sites drilled by Leg 9 in the equatorial sediment lens (Sites 77 through 84, Figure 1, Table 1) penetrated basalt, and the paleontological estimates of the ages of the immediately overlying sediment

\footnotetext{
${ }^{1}$ Scientific contribution No. 1732, Lamont-Doherty Geological Observatory.
}

are presented in Table 2. (For details of the age calculations for each site see the appropriate site report.) The oldest sediments encountered are of upper Eocene age (Site 77), the youngest basal sediments occur in sites closest to the crest of the East Pacific Rise (Sites 82 and 83). If the paleontological age of the overlying sediment is assumed to closely approximate the age of the underlying lithosphere and if the position of the spreading center has not changed then average rates of sea floor spreading can be calculated for four time intervals since the Eocene (Table 3). Two objections might be raised to these assumptions. First the sediment basaltic basement contact is intrusive. Intrusive emplacement of the basalts is indicated by glassy margins at the basalt contacts, by baked zones in the overlying sediments, and by sediment zenoliths in the lavas. Thus, these basalts are most likely sills and could be substantially younger than the overlying sediment. Secondly, there is evidence from magnetic anomalies (Herron, 1971; and Sclater and Bell, 1971) that the spreading center shifted during the last 10 million years. Our estimates of basement age will be in error only if a substantial thickness of sediment is buried beneath the basalts. The decreasing age of the basal sediments with increasing proximity to the East Pacific Ridge Crest (Figure 2) argues strongly against random emplacement of sills. The poorly consolidated nature of the sediments in this region, even near the base of the section, make it unlikely that these sediments could support a basalt sill. It is more likely that even if intrusion occurred well out on the flanks of the East Pacific Rise the basalt would flow along the basement-sediment interface. Under these circumstances, the paleontological estimate of basement age would be altered only to the extent that the silling process destroyed, incorporated or buried some basal sediment. Recognizing the possible errors of our estimated basement ages we drilled an additional site (Site 80) directly south of Site 79 to test whether silling was distorting age estimates. Reasoning that if the Pacific plate was moving parallel to the major fracture zones to the north (for example, Clipperton, Clarion, etc.) during the late Oligocene and early Miocene, the magnetic anomalies and time lines in the basement should trend at right angles to these fracture zones. Two sites drilled on a north-south line should then have similar basement ages providing there are no 


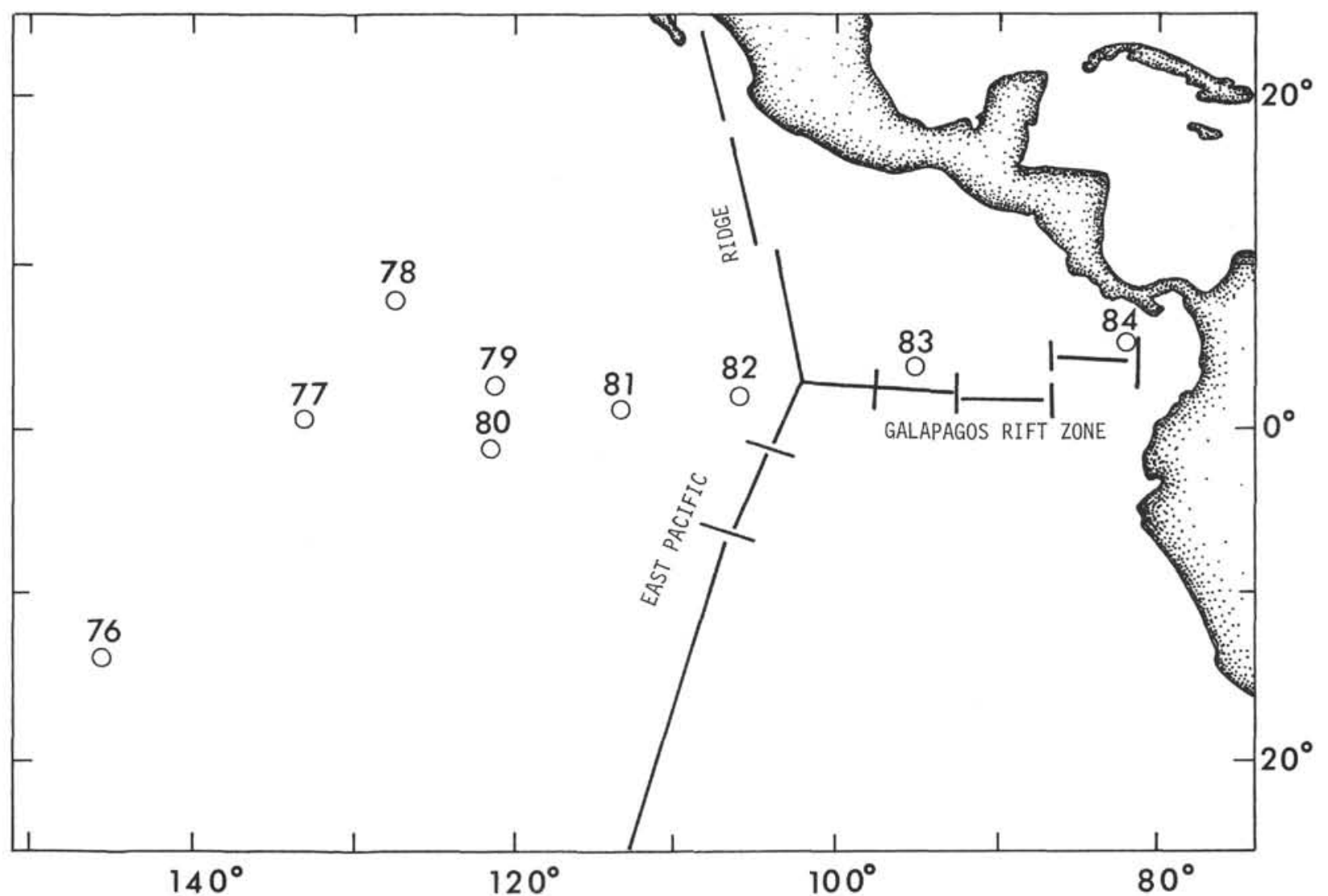

Figure 1. Location of Leg 9 drilling sites.

intervening fracture zones. The age of the basal sediments at Sites 79 and 80 is lower Miocene (Globorotalia kugleri Foraminiferal Zone) with an estimated age of about 21 million years B.P. It seems improbable that sills would intrude remote columns of sediment at the same stratigraphic level, if this stratigraphic level was other than the sediment basement contact. We suggest therefore that the silling process has not substantially altered the reliability of the paleontological age of the basal sediments as an estimate of the age of the underlying lithosphere.

Our estimated basement ages suggest that the rate of movement of the Pacific plate relative to the East Pacific Rise crest accelerated during the Cenozoic from the Eocene to the mid-Miocene $(8 \mathrm{~cm} / \mathrm{yr}$ to $>13 \mathrm{~cm} / \mathrm{yr})$ and then decreased to about $6 \mathrm{~cm} / \mathrm{yr}$ since the Middle Miocene (Table 3; Figure 3). This latter spreading rate is in agreement with present rates interpreted from magnetic anomaly patterns to the north and south but the earlier rates are not. Another explanation for the disparity in spreading rates is that the position of the spreading axis changed about 10 to 20 million years ago.
One argument against the accelerating motion of the plate relative to the rise crest is the lack of evidence in the anomaly petterns north and south of the equatorial region for acceleration (Herron, in press). To accomodate a differential movement in the now rigid Pacific plate, a set of fracture zones north and south of the equator extending across the Pacific would have to have existed with dextral displacement on the northern set and sinistral displacement on the southern set. There is no topographic evidence of such features. The Clipperton Fracture Zone has the proper sense of displacement, however, there is no topographic evidence to suggest that it extends all the way across the Pacific plate. The displacement on the fracture zones to the south is not clearly understood. Herron (1971) has pointed out that three distinct patterns of spreading during the Cenozoic are indicated by anomaly patterns of the Central Pacific (Figure 4). The first of these is parallel to the north-northeast trend of the east Pacific Ridge south of the Equator and contains only anomalies generated within the last 20 million years (Anomaly 6 of Pitman and others, 1968). The second pattern trends north-northwestward parallel 
TABLE 1

Operational Statistics for Leg 9, DSDP

\begin{tabular}{|c|c|c|c|c|c|c|c|c|c|c|c|c|}
\hline \multirow[b]{2}{*}{ Hole } & \multirow[b]{2}{*}{ Latitude } & \multirow[b]{2}{*}{ Longitude } & \multicolumn{2}{|c|}{ Water Depth } & \multicolumn{2}{|c|}{ Penetration } & \multirow{2}{*}{$\begin{array}{l}\text { Number } \\
\text { of Cores }\end{array}$} & \multicolumn{2}{|c|}{ Cored } & \multicolumn{2}{|c|}{ Recovery } & \multirow{2}{*}{$\begin{array}{l}\text { Per Cent } \\
\text { Recovery }\end{array}$} \\
\hline & & & (Feet) & (Meters) & (Feet) & (Meters) & & (Feet) & (Meters) & (Feet) & (Meters) & \\
\hline 76 & $14^{\circ} 05.90^{\prime} \mathrm{S}$ & $145^{\circ} 39.64^{\prime} \mathrm{W}$ & 15,085 & 4597.92 & 90 & 27.43 & 1 & 30 & 9.1 & 30 & 9.1 & 100.0 \\
\hline $76 \mathrm{~A}$ & $14^{\circ} 05.90^{\prime} \mathrm{S}$ & $145^{\circ} 39.64^{\prime} \mathrm{W}$ & 15,085 & 4597.92 & 90 & 27.43 & 2 & 60 & 18.3 & 55 & 16.8 & 91.7 \\
\hline 77 & $00^{\circ} 28.90^{\prime} \mathrm{N}$ & $133^{\circ} 13.70^{\prime} \mathrm{W}$ & 14,077 & 4290.68 & 30 & 9.14 & 1 & 30 & 9.1 & 1 & 0.3 & 3.3 \\
\hline $77 \mathrm{~A}$ & $00^{\circ} 28.90^{\prime} \mathrm{N}$ & $133^{\circ} 13.70^{\prime} \mathrm{W}$ & 14,077 & 4290.68 & 60 & 18.28 & 2 & 60 & 18.3 & 30 & 9.1 & 50.0 \\
\hline $77 \mathrm{~B}$ & $00^{\circ} 28.90^{\prime} \mathrm{N}$ & $133^{\circ} 13.70^{\prime} \mathrm{W}$ & 14,077 & 4290.68 & 1579 & 481.28 & 54 & 1549 & 472.1 & 1436 & 437.7 & 92.7 \\
\hline $77 \mathrm{C}$ & $00^{\circ} 28.90^{\prime} \mathrm{N}$ & $133^{\circ} 13.70^{\prime} \mathrm{W}$ & 14,077 & 4290.68 & 330 & 100.58 & 1 & 30 & 9.1 & 25 & 7.6 & 83.3 \\
\hline 78 & $07^{\circ} 57.00^{\prime} \mathrm{N}$ & $127^{\circ} 21.35^{\prime} \mathrm{W}$ & 14,363 & 4377.85 & 1051 & 302.34 & 37 & 1051 & 320.3 & 990 & 301.8 & 94.2 \\
\hline 79 & $02^{\circ} 33.02^{\prime} \mathrm{N}$ & $121^{\circ} 34.00^{\prime} \mathrm{W}$ & 15,006 & 4573.84 & 1359 & 414.22 & 17 & 437 & 133.2 & 396 & 120.7 & 90.6 \\
\hline $79 \mathrm{~A}$ & $02^{\circ} 33.02^{\prime} \mathrm{N}$ & $121^{\circ} 34.00^{\prime} \mathrm{W}$ & 15,006 & 4573.84 & 944 & 287.73 & 4 & 120 & 36.6 & 114 & 34.8 & 95.0 \\
\hline 80 & $00^{\circ} 57.72^{\prime} \mathrm{S}$ & $121^{\circ} 33.22^{\prime} \mathrm{W}$ & 14,472 & 4411.07 & 655 & 199.64 & 6 & 139 & 42.4 & 131 & 39.9 & 94.2 \\
\hline $80 \mathrm{~A}$ & $00^{\circ} 57.72^{\prime} \mathrm{S}$ & $121^{\circ} 33.22^{\prime} \mathrm{W}$ & 14,472 & 4411.07 & 388 & 118.26 & 5 & 150 & 45.7 & 150 & 45.7 & 100.0 \\
\hline 81 & $01^{\circ} 26.49^{\prime} \mathrm{N}$ & $113^{\circ} 48.54^{\prime} \mathrm{W}$ & 12,681 & 3865.18 & 1343 & 409.34 & 7 & 129 & 39.3 & 129 & 39.3 & 100.0 \\
\hline 82 & $02^{\circ} 35.48^{\prime} \mathrm{N}$ & $106^{\circ} 56.52^{\prime} \mathrm{W}$ & 12,161 & 3706.68 & 703 & 214.27 & 7 & 165 & 50.3 & 151 & 46.0 & 91.5 \\
\hline $82 \mathrm{~A}$ & $02^{\circ} 35.48^{\prime} \mathrm{N}$ & $106^{\circ} 56.52^{\prime} \mathrm{W}$ & 12,161 & 3706.68 & 1364 & 110.94 & 3 & 90 & 27.4 & 87 & 26.5 & 96.7 \\
\hline 83 & $04^{\circ} 02.8^{\prime} \mathrm{N}$ & $95^{\circ} 44.25^{\prime} \mathrm{W}$ & 11,961 & 3645.72 & 792 & 241.40 & 9 & 201 & 61.3 & 153 & 46.6 & 76.1 \\
\hline $83 \mathrm{~A}$ & $04^{\circ} 02.8^{\prime} \mathrm{N}$ & $95^{\circ} 44.25^{\prime} \mathrm{W}$ & 11,961 & 3645.72 & 720 & 219.45 & 16 & 480 & 146.3 & 464 & 141.4 & 96.7 \\
\hline 84 & $05^{\circ} 44.92^{\prime} \mathrm{N}$ & $82^{\circ} 53.29^{\prime} \mathrm{W}$ & 10,159 & 3096.47 & 833 & 253.90 & 30 & 833 & 253.9 & 703 & 214.3 & 84.4 \\
\hline Total & & & 230,881 & 70372.68 & 11,331 & 3435.63 & 202 & 5554 & 1692.7 & 5045 & 1537.6 & 90.9 \\
\hline
\end{tabular}


TABLE 2

Age of Basal Sediments

\begin{tabular}{cllc}
\hline Site & \multicolumn{1}{c}{ Latitude } & \multicolumn{1}{c}{ Longitude } & Age $\left(10^{6}\right.$ years $)$ \\
\hline 76 & $14^{\circ} 05.9^{\prime} \mathrm{S}$ & $145^{\circ} 39.6^{\prime} \mathrm{W}$ & $2-3$ \\
77 & $00^{\circ} 28.9^{\prime} \mathrm{N}$ & $133^{\circ} 13.7^{\prime} \mathrm{W}$ & $36 \pm 1$ \\
78 & $07^{\circ} 57^{\prime} \mathrm{N}$ & $127^{\circ} 21.35^{\prime} \mathrm{W}$ & $33 \pm 1$ \\
79 & $02^{\circ} 33.2^{\prime} \mathrm{N}$ & $121^{\circ} 34^{\prime} \mathrm{W}$ & $21-22$ \\
80 & $00^{\circ} 57.7^{\prime} \mathrm{S}$ & $121^{\circ} 33.22^{\prime} \mathrm{W}$ & $21-22$ \\
81 & $01^{\circ} 26.49^{\prime} \mathrm{N}$ & $113^{\circ} 48.54^{\prime} \mathrm{W}$ & $14-15$ \\
82 & $02^{\circ} 35.48^{\prime} \mathrm{N}$ & $106^{\circ} 56.52^{\prime} \mathrm{W}$ & $9-10$ \\
83 & $04^{\circ} 02.8^{\prime} \mathrm{N}$ & $95^{\circ} 44.25^{\prime} \mathrm{W}$ & $10-11$ \\
84 & $05^{\circ} 44.92^{\prime} \mathrm{N}$ & $82^{\circ} 53.29^{\prime} \mathrm{W}$ & $8-9$ \\
\hline
\end{tabular}

TABLE 3

Spreading Rates

\begin{tabular}{|c|c|c|c|c|c|c|c|}
\hline \multirow[b]{2}{*}{ Site } & \multirow{2}{*}{$\begin{array}{c}\text { Distance to } \\
\text { Ridge Crest }(\mathrm{km})\end{array}$} & \multirow[b]{2}{*}{ Longitude } & \multirow{2}{*}{$\begin{array}{l}\text { Age of Bottom } \\
\text { Million of Yrs }\end{array}$} & \multicolumn{3}{|c|}{ Distance between Sites } & \multirow{2}{*}{$\begin{array}{l}\text { Spreading Rate } \\
\mathrm{m} / 10^{3} \text { Yrs }\end{array}$} \\
\hline & & & & (Degrees) & (Naut. Mi.) & $(\mathrm{km})$ & \\
\hline \multirow[t]{2}{*}{77} & 3359 & $133^{\circ} 13.7^{\prime} \mathrm{W}$ & $36-37-$ & & & & \\
\hline & & & & & 700 & 1273 & 79.5 \\
\hline \multirow[t]{2}{*}{79} & 2086 & $121^{\circ} 34.0^{\prime} \mathrm{W}$ & $21-22<$ & & & & \\
\hline & & & & $7^{\circ} 4$ & 474 & 806 & 124.0 \\
\hline \multirow[t]{2}{*}{81} & 1280 & $113^{\circ} 48.54^{\prime} \mathrm{W}$ & $14-15$ & & & & \\
\hline & & & & $6^{\circ} 41^{\prime}$ & 400 & 731 & 133.0 \\
\hline \multirow[t]{2}{*}{82} & 549 & $106^{\circ} 56.52^{\prime} \mathrm{W}$ & $9-10$ & & & & \\
\hline & & & & $5^{\circ} 60^{\prime}$ & 300 & 549 & 61.0 \\
\hline $\begin{array}{l}\text { Ridge } \\
\text { Crest }\end{array}$ & 0 & $102^{\circ} \mathrm{W}(?)$ & $0-0$ & & & & \\
\hline 83 & 797 & $94^{\circ} 44.3^{\prime} \mathrm{W}$ & $10-11-$ & $=7^{\circ} 16^{\prime}$ & 436 & 797 & 72.0 \\
\hline
\end{tabular}

or subparallel to the trend of the Chile Ridge and the East Pacific Ridge north of the Equator, and includes anomalies generated between about 80 and 10 to 20 million years ago. The third pattern of magnetic anomalies trends east-west near the Galapagos Islands and has been produced by spreading along the Galapagos Rift zone during about the last 10 million years. These data indicate that the East Pacific Ridge, as it now exists in the Central Pacific, has persisted only for about the past 10 million years. Herron (1971) proposes that our basement ages can be interpreted not as an acceleration of sea floor spreading during the Cenozoic but rather as a shift in the position of the spreading axis in the Equatorial region from $115^{\circ} \mathrm{W}$ to $102^{\circ} \mathrm{W}$ about 10 million years ago (Figure 5). She places the older Ridge axis between Sites 79-80 and
81. According to her model, Sites $77,78,80$ and 81 were drilled into basement produced by the old spreading center at $115^{\circ} \mathrm{W}$ with Sites 77 through 80 on the western flank and Site 81 on the eastern flank (Figures 5 and 6). The rapid spreading rate of $12 \mathrm{~cm} / \mathrm{yr}$ between Sites $79-80$ and 81 would be interpreted not as a half rate but as a full rate giving a half rate of about $6 \mathrm{~cm} / \mathrm{yr}$. Site 82 on the other hand was drilled on the western edge of the crust produced by the present spreading center at $102^{\circ} \mathrm{W}$. The distance between sites 81 and 82 may not be the result of spreading from a single spreading axis, but rather from two.

Whichever interpretation is accepted to explain the basement ages and resultant spreading rates, both models involve a change in the pattern of spreading 


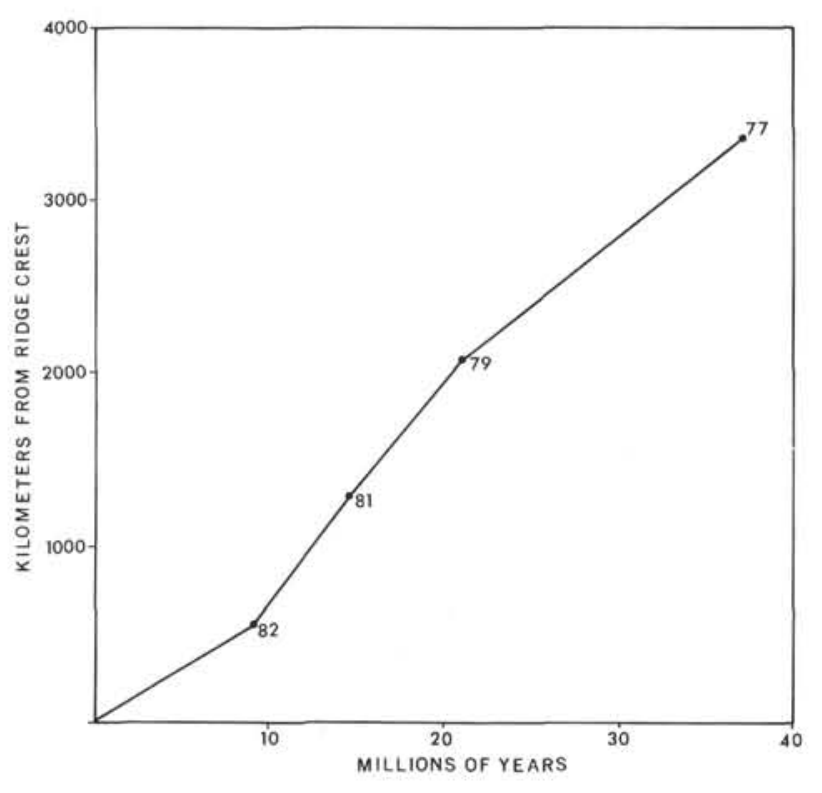

Figure 2. Age of basal sediments collected on Leg 9 versus distance from ridge crest.

of the Pacific plate about 10 to 20 million years ago. A second problem related to lateral spreading in the equatorial Pacific is the abrupt increase in sediment thickness on either flank of the east Pacific Rise about 500 kilometers from the crest. Ewing and Ewing (1967) have suggested that this thickening was due to a pause in spreading of some tens of millions of years during which the sediment thickness on the outer flanks of the ridge accumulated. About 10 million years ago spreading resumed and the new crust created by this most recent phase is covered by a thin veneer of sediments deposited during the last 10 million years. Site 82 was drilled to test this hypothesis. If the Ewing (1967) model is correct, the basement should be 40 to 50 million years old (Eocene) at this site. Results from our earlier sites indicated that this would not be the case. At Site 82, 214 meters of sediment was penetrated and drilling was terminated in basalt. The age of the sediments overlying the basalt is estimated at 9 million years. If this represents a reasonable approximation of the age of the lithosphere then it is improbable that the increased thickness of sediment was due to a spreading pause. It might be argued that Site 82 was too far to the east to test this hypothesis, but the age of the sediments immediately overlying basement at Site 81 (13 million years B.P.) precludes a long spreading pause.

What then can explain the abrupt change in sediment thickness on the flanks of the East Pacific Rise? The hypothesis of the shifting spreading center provides one possible explanation. If the spreading center shifted eastward $6^{\circ}$, as suggested by Herron (in press), some 10 million years ago and the spreading prior to 10 million years B.P. (from the old spreading center now at $115^{\circ} \mathrm{W}$ ) had a half rate of about $6 \mathrm{~cm} / \mathrm{yr}$, then the new spreading center would have formed under sediments that were deposited for more than 20 million years.

If we assume that the accumulation rates prior to 10 million years B.P. in this area were similar to the rates since then (about $20 \mathrm{~m} / 10^{6} \mathrm{yrs}$,) the new spreading center would have begun under sediments some 400 meters thick. Although the sediments are not quite this thick close to the zone of thickening, this is not a critical point since so many assumptions are involved. Nevertheless as spreading from the new center continued, an abrupt change in sediment thickness would have occurred between those sediments overlying the crust produced by the new spreading center and those deposited on the older crust. Another consequence of this model is that if the spreading center jumped, there should be a thinning of sediments over the old spreading center at $115^{\circ} \mathrm{W}$. Herron's model (op. cit.) assumes that the eastern edge of the crust produced by the old spreading center at $115^{\circ} \mathrm{W}$ should be about $109^{\circ} \mathrm{W}$ and have an age of about 22 million years B.P., therefore being twice as old as the crust at $115^{\circ} \mathrm{W}$. Since the average accumulation rate at our Site $81\left(21 \mathrm{~m} / 10^{6} \mathrm{yrs}\right)$ near the old spreading axis is similar to that at Site 82 then one would expect twice the thickness of sediment to have accumulated at $109^{\circ} \mathrm{W}$ than at $115^{\circ} \mathrm{W}$ according to the Herron model. Examination of the Vema 24 seismic reflection records on an east-west run along the axis of the equatorial sediment lens indicates that thinner sediments occur in the neighborhood of $115^{\circ} \mathrm{W}$ than between $115^{\circ} \mathrm{W}$ and $109^{\circ} \mathrm{W}$. Additional evidence for a rapid shift of the spreading center is provided by Sclater and Bell (in press), who have proposed that north of the equatorial region the spreading axis also jumped from the region of the Mathematician seamounts eastward to its present position about five million years ago.

A third possibility is that prior to 9 million years B.P. spreading was nearly east-west parallel to the major Pacific fracture zones (Clipperton, Clarion, etc.). During this spreading period one band of sediment remained beneath the equator (region of highest productivity and ocean floor accumulation) producing thick deposits of sediment. Since 9 million years B.P. the direction of spreading has been oblique to the Equator, moving any given segment of the Pacific plate across the Equator thereby not allowing time for thick sediment accumulations to develop but rather spreading the high accumulations formed under the Equator over a broader area.

Of the various possible interpretations, we think the shifting spreading center best explains our basement ages and the change in sediment thickness observed by Ewing and Ewing (1967). 


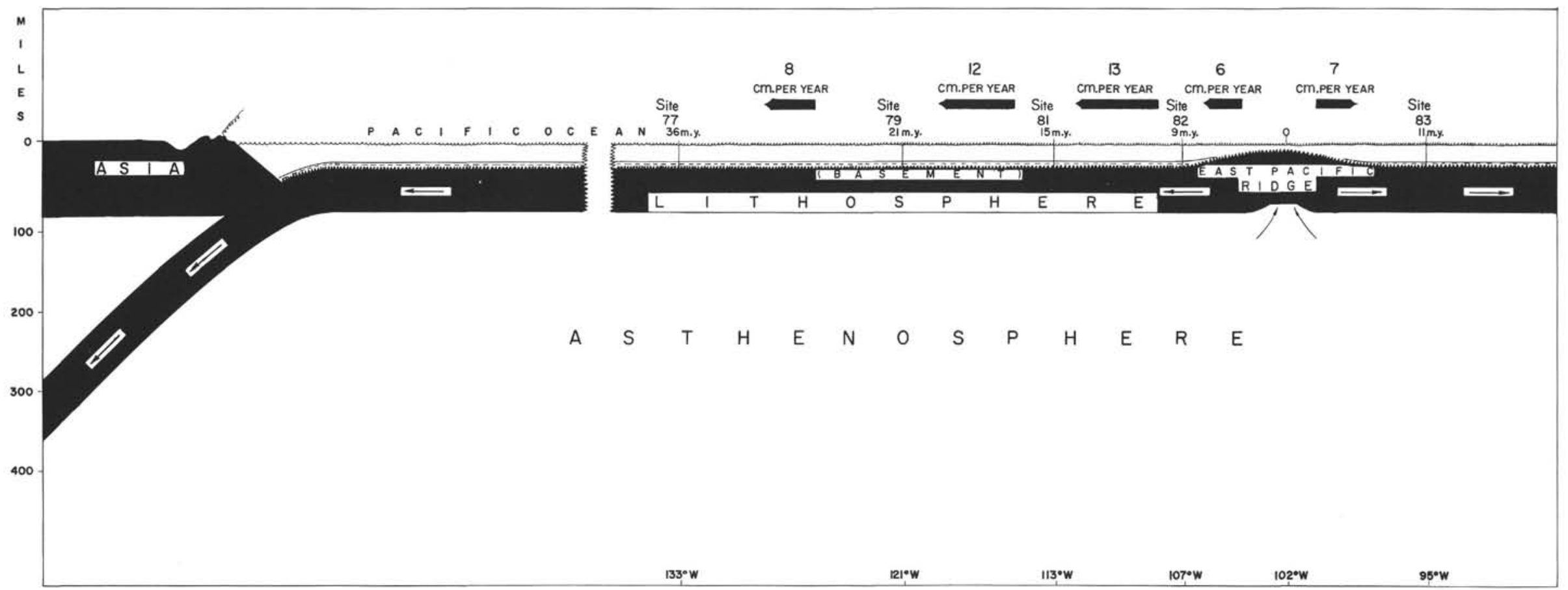

Figure 3. Hypothetical profile of the Pacific plate giving rates of spreading assuming a constant spreading center during the last 35 million years. 


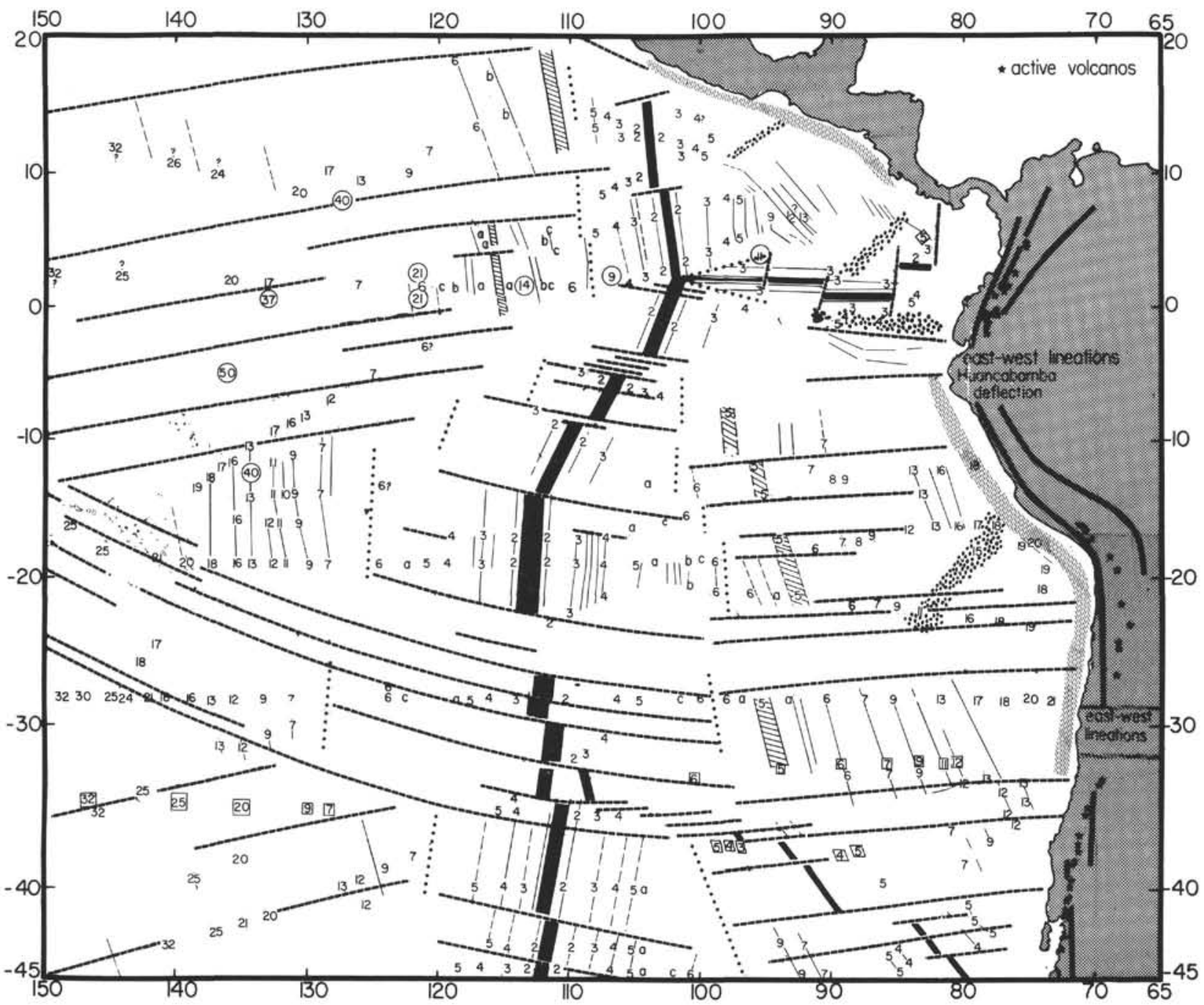

Figure 4. Pacific anomaly pattern after Herron (1971).

\section{Latitudinal Motion of the Pacific Plate}

There are now several lines of evidence that suggest a substantial northward motion of the Pacific plate during the Cenozoic. Francheteau and others (1970) have suggested on the basis of seamount magnetization vectors that the Pacific plate has moved northward some $30^{\circ}$ of latitude since the Cretaceous. Herron (in press) in her examination of low latitude Pacific magnetic anomalies has pointed out that the amplitude of anomalies just north of the equator are in accord with the direction of motion proposed by Francheteau and others (1970). On the other hand, the sediment thickness data of Ewing and others (1968) conforms well with the belt of high equatorial productivity, thereby apparently precluding large latitudinal displacements since the Cretaceous. We know from equatorial Pacific piston core data (Hays and others, 1969) that accumulation rates during the last 700,000 years are maximal at or very near the equator. Assuming that the equatorial current system and its associated high productivity divergence must always be at or very near the equator then this zone of rapid accumulation becomes a useful marker for the position of the paleoequator with respect to the Pacific plate. With the exception of Site 81 , Sites 77 through 84 were heavily cored. This permits us to measure fairly accurately the thickness of sediment accumulated during given intervals of time. An interesting pattern emerges if Sites 77, 78, 79 and 80 are arranged according to latitude. We have shown graphically in Figure 7 the thickness of sediment accumulated during five million year increments from the lower Miocene to the Recent. The data from piston cores definitely shows that the highest accumulation rates during the last 700,000 years were centered on the equator. This is nearly true for the last five million years although the maximum accumulation during this interval appears to be slightly north of the equator. Between 5 and 10 million years B.P., the zone of maximum accumulation is definitely north of the 


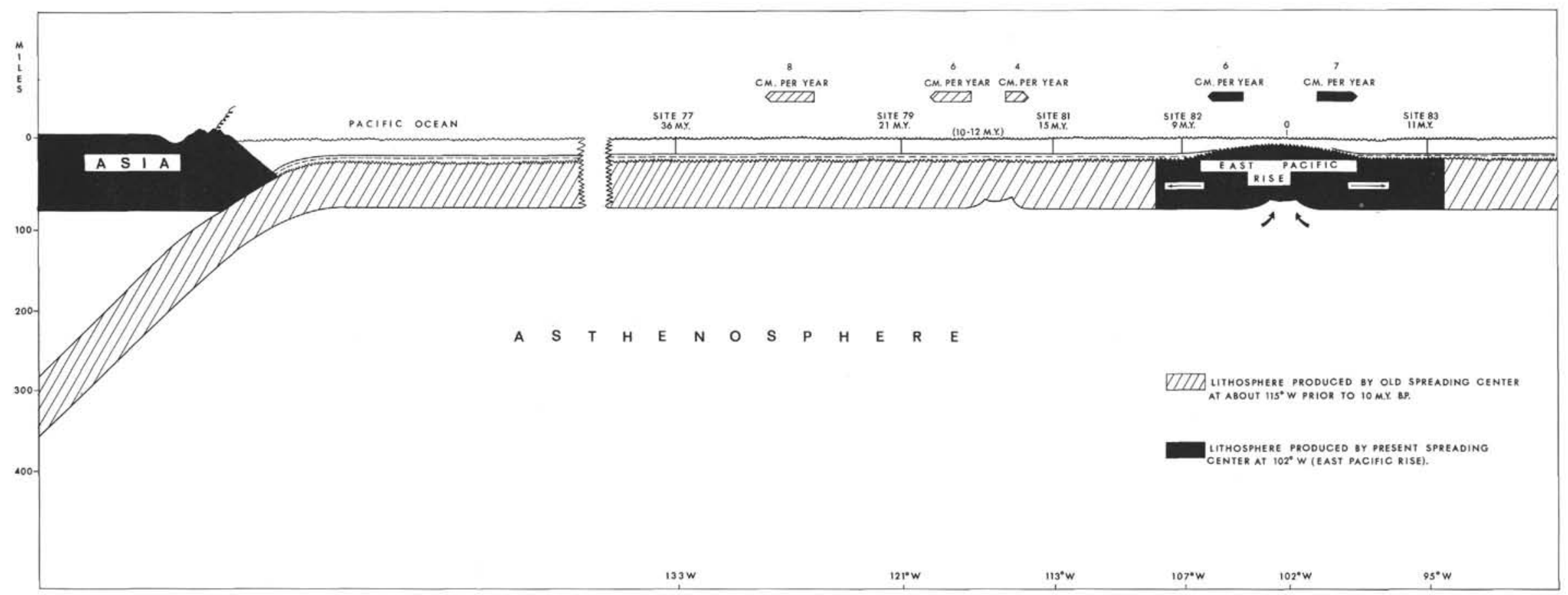

Figure 5. Hypothetical profile of the Pacific plate assuming the spreading center moved from $115^{\circ} \mathrm{W}$ to $102^{\circ} \mathrm{W}$ at about 10 million years $B . P$. 


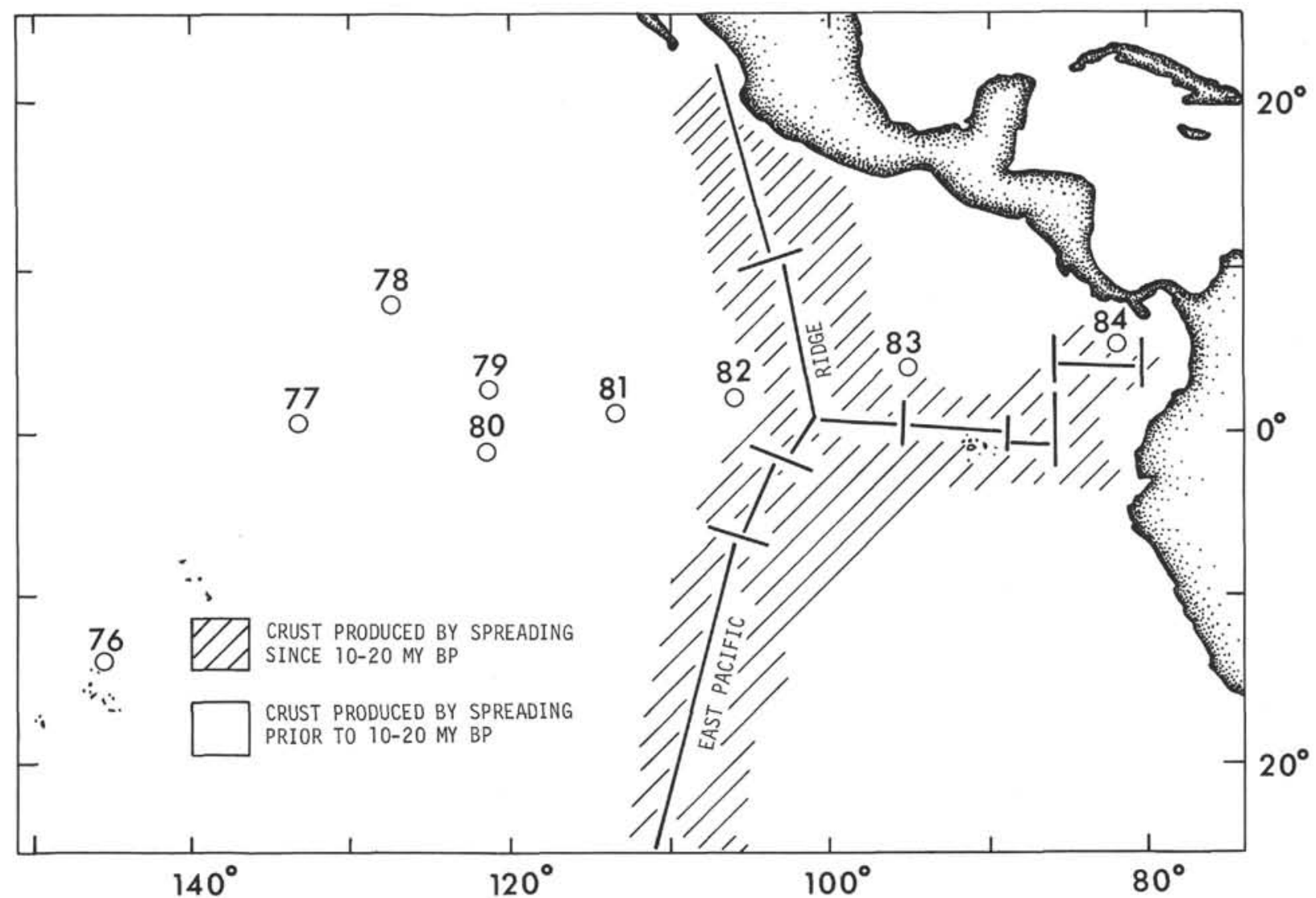

Figure 6. Crust produced by spreading since 10 million years $B . P$.

equator by at least 2 degrees. This pattern of maximum thickness centered between 2 degrees and 4 degrees north of the equator also occurred between 10 and 15 million years B.P. and 15 to 20 million years B.P. A very similar pattern was observed by Leg 8 scientists on their $140^{\circ} \mathrm{W}$ transverse (Sutton and others, 1971). Two possible explanations can be offered for this pattern. First, that the zone of maximum productivity, currently centered on the equator, shifted from a more northerly position $\left(2^{\circ}\right.$ to $\left.4^{\circ} \mathrm{W}\right)$ where it was located between 20 and 10 million years B.P. to its present equatorial position during the last 10 million years. Second, that the Pacific plate had a nearly westerly motion between 20 and 10 million years B.P., and that this motion changed so as to have a northerly component during the past 10 million years.

The first alternative seems unlikely since the present high productivity is associated with the equatorial divergence and this divergence is located on the equator because the Coriolis force is zero there. It is unlikely that this divergence would have shifted far from the equator in the past. It also seems fortuitous that the zone of high productivity would shift at the same time as the major reorientation of relative plate motions described above.
We favor the second interpretation of the sediment thickness displacement. This interpretation indicates that a change in the absolute direction of the Pacific plate occurred about 10 million years ago. The change in the trend of magnetic anomalies about the time of Anomaly 5-noted from the Juan de Fuca-Gorda ridge in the north to the Eltanin Fracture Zone in the south (Vine, 1966; Menard and Atwater, 1968; Chase and others, 1970); Herron, and Hays, 1969; Sclater and Bell, 1971; Herron, 1971) - could also be interpreted as a product of this absolute change in plate motion. Our interpretation also indicates that during the Neogene most of the motion of the Pacific plate was nearly due west and only during the last 10 million years has it had a northerly component resulting in a northward displacement of only a few degrees.

Francheteau and others (1970) have suggested that the Pacific plate north of the Tuamotus has been migrating northward since the late Cretaceous. According to their interpretation of the magnetization of seamounts, the Hawaiian seamounts formed about 100 million years B.P., now lie $30^{\circ}$ north of the original position. Our data, of course, covers only a small 


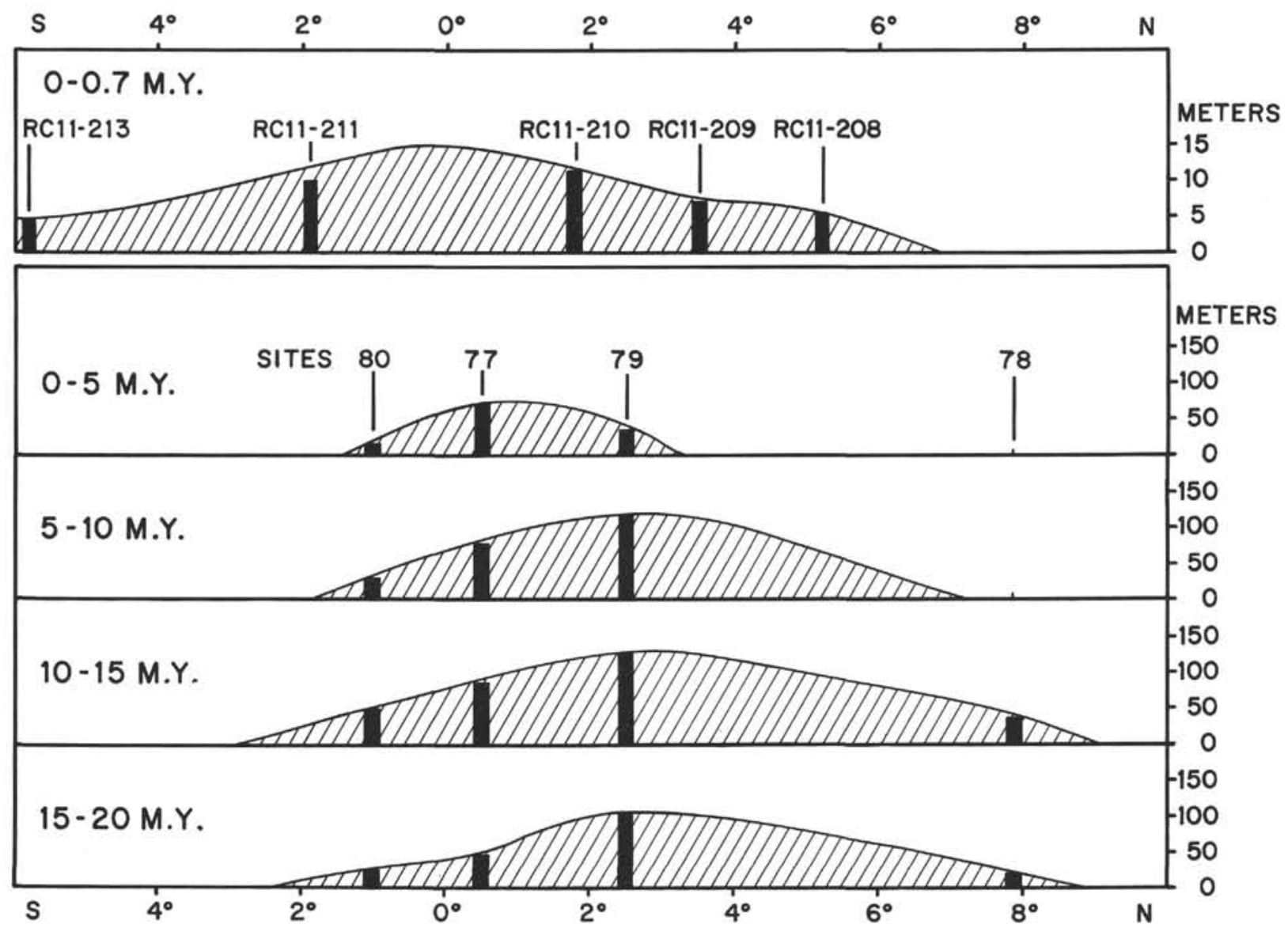

Figure 7. Thickness of sediment recovered by Leg 9 at sites 77, 78, 79 and 80 in 5 million year increments as well as piston core data for the last 700,000 years (Hays, et al, 1969).

segment of this interval but we have no evidence for northward motion between about 10 and 20 million years B.P.

From our data we conclude that between 20 million years B.P. (and probably earlier; the data from Leg 8 Tracey et al., 1971 suggest as early as 30 to 35 million years B.P.) the Pacific plate moved nearly due west. Around 10 million years B.P., a major rearrangement of plate motions occurred in the Pacific. In some parts of the Pacific this rearrangement involved the formation of a new spreading center considerably removed from the old spreading center (Herron and Hayes, 1969; Herron, 1971; Sclater and Bell, 1971), but elsewhere in the Pacific, north of the Eltanin Fracture Zone, it involved a change in the absolute direction of spreading which produced a northerly component in the eastern equatorial Pacific. It is unlikely that such a major reorientation of plate motions occurred abruptly or that it started and ended at the same time throughout the Pacific. It is probable, however, that by about 10 million years B.P. the rearrangement was nearly completed throughout the Pacific and the present regime of spreading established.
World Pattern of Spreading Before and After Anomaly 5

The concepts of plate tectonics (McKenzie and Parker, 1967; Morgan, 1968; LePichon, 1968) clearly indicate that the motions of all lithospheric plates are interrelated and a change in the motion of one will induce changes in the motion of others. One might then expect that the change in absolute motion of the Pacific plate about 10 million years ago would be reflected in other plate motions. Ewing and Ewing (1967) were the first to suggest that a worldwide change in plate motion occurred about 10 million years ago. The abrupt outward thickening of sediment that they observed could be due either to a change in spreading rate (such as, the pause in spreading prior to 10 million years B.P. which they suggested) or to a relocation of the spreading center. LePichon (1968) noted a worldwide change in the anomaly pattern about the time of Anomaly 5. Since then several detailed studies of the anomaly patterns in individual ocean basins have been made. In the North Atlantic north of the Azores Gibralter ridge a striking discontinuity exists in spreading rates prior to and after Anomaly 5 (Pitman and Talwani 1971). Between Anomaly 5 and Anomaly 13 
the spreading rate was slow $(0.75 \mathrm{~cm} / \mathrm{yr})$, whereas, since Anomaly 5 time the spreading rate has been between 1 and $2 \mathrm{~cm} / \mathrm{yr}$. In this area the best explanation for the change in sediment thickness has been proposed by Ewing and Ewing (1967). South of the Azores Gibralter ridge there is no striking discontinuity in spreading rates before and after Anomaly 5 time. The slowest spreading rates in this region according to Pitman and Talwani (1971) occur between Anomaly 5 and 13.

In the South Atlantic the evidence from magnetic anomalies (Dickson et al., 1968; Dickson et al., in press) and DSDP drilling (Maxwell et al., 1970) suggest that the Cenozoic spreading rates in this area have been nearly constant. The change in sediment thickness on the flanks of the mid-Atlantic ridge in the South Atlantic remains a problem.

The Indian Ocean anomaly patterns have recently been studied in detail by McKenzie and Sclater (in press). They have shown that spreading was very slow between Anomaly 5 and 24 on the southeast Indian ridge and Carlsburg ridge. None of the fracture zones on the central Indian ridge offset anomalies older than Anomaly 5, so that the structure of the crest of this ridge was formed by a change in spreading direction since mid-Miocene.

In the Indian Ocean then, as in the North Atlantic, the best explanation of the change in sediment thickness is a pause in spreading prior to Anomaly 5. Thus, in all the major ocean basins except the South Atlantic, a change in the pattern of spreading occurred about Anomaly 5 (10 million years B.P.), but the magnitude of the change varied considerably in different oceans.

\section{Pacific Margin Consequences Of Mid-Miocene Change in Plate Motions}

With the publication of Isacks and others (1968) and subsequent papers, geologists have become increasingly aware of the importance of the interaction between lithospheric plates in the interpretation of tectonics in marginal areas. A mid-Miocene change in the absolute direction of plate motion should have had tectonic manifestations in the marginal areas of the Pacific. We might expect changes in the pattern and type of volcanism and epeirogenic and orogenic movements.

The relationship between the length of the seismic zone under island arcs and calculated rates of underthrusting have been examined by LePichon (1968) and Isacks and others (1968). The length of the seismic zone beneath Indo-Pacific Island arcs agrees with the predicted length from calculated slip rates if it is assumed that the underthrusting began about 10 million years B.P. (Figure 8). Isacks and others (1968) offer several possible factors that may control the length of the seismic zone beneath island arcs:

1) It is determined only by the rate and duration of underthrusting.
2) It is limited by the depth of the mesosphere.

3) It is dependent on the rate of underthrusting and the rate of assimilation of the underthrust slab.

4) The underthrust slab may break and a lower portion become detached from the part connected to the sea floor.

For Indo-Pacific island arcs we favor the first explanation. Most of the lengths of the seismic zones can be explained by slip rate if we assume that the present underthrusting phase started about 10 million years B.P.

Late Cenozoic orogeny and explosive volcanic activity are characteristic of the island arcs of the western Pacific. Post mid-Miocene folding and uplift are responsible for major portions of the relief of the island arcs. Examples of this include the New Zealand Alps of South Island and the backbone range of Japan.

In at least two arcs, Japan and the Philippines, the late Miocene orogenesis was preceded by a period of epeirogenic subsidence and marine transgression in the Lower and Middle Miocene. The recent phase of explosive volcanism began in all cases since the Middle Miocene. This is important because of the apparent relationship between the underthrust lithosphere and explosive andesitic and rhyolitic volcanoes.

\section{Volcanicity}

Several authors have observed that the currently active andesitic volcanoes overlie that part of the underthrust lithosphere where earthquake foci occur at a depth of greater than 100 kilometers (Honda, 1934; Wadati, 1934; Gutenberg and Richter, 1954; Benioff, 1954). Dickinson and Hatherton (1967) have stated, after an examination of published data on island arcs, that andesitic volcanoes never occur within the zone of shallow seismicity between the trench and the island arc. Typically, the first line of active volcanoes mark the arc-side boundary of the earthquake foci that lie between 0 and $100 \mathrm{~km}$ depth.

Assuming that only when the underthrust oceanic plate reaches a depth of between 100 and 200 kilometers are the conditions met for the production of andesitic magma, then the initiation of this kind of volcanism should record the time when the underthrust plate reached this depth. If the major reorganization of plate motion in the Middle Miocene discussed above initiated a new regime of underthrusting, then the Recent phase of volcanism in the western Pacific should have begun since the Middle Miocene. It is beyond the scope of this report to discuss in detail the volcanic and geologic history of all the arcs and arc-like structures in the western Pacific, but to test this hypothesis we will look at three areas: New Zealand and the Aleutians where the seismic zone is shallow, and Japan where the seismic zone is deep. 


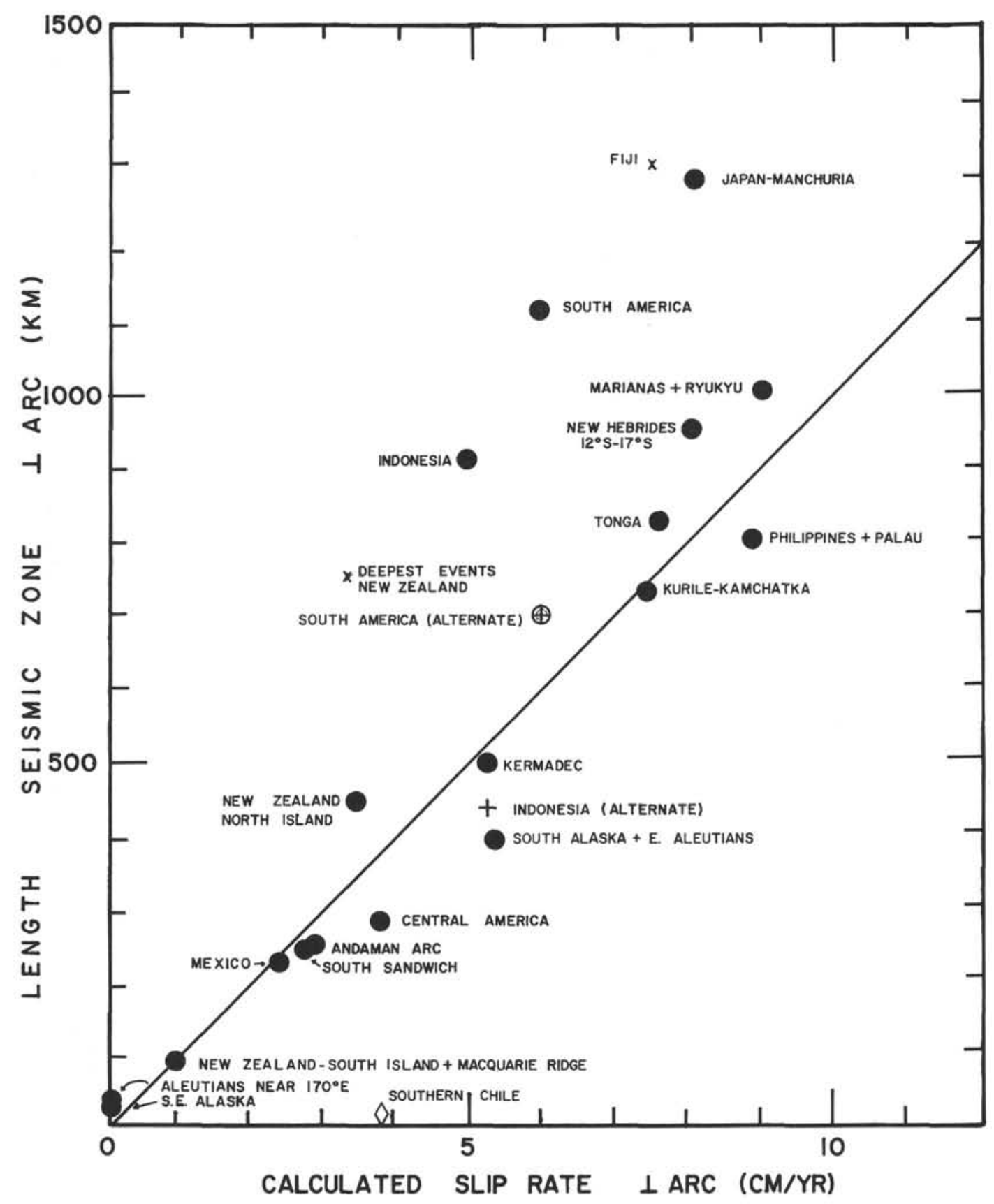

Figure 8. Slip rate vs. length of seismic zone after Isacks et al.(1968). Alternate points (cross and circled cross) for South America and Indonesia assume that the gap in the seismic zone beneath these areas is caused by a gap in the underthrust lithospheric plate, and the earthquake foci occurring below the gap are produced from a lithospheric slab underthrust prior to 10 million years $B$. $P$. The length of the seismic zone calculated for the alternate points is the length of the continuous seismic zone above the gap in seismicity. 


\section{New Zealand and Aleutians Arcs}

The deepest earthquakes in the continuous seismic zone beneath both New Zealand and the Aleutians are shallow relative to the earthquakes beneath Japan so we would expect the beginning of the recent phase of volcanism to be young compared with Japan.

In New Zealand the recent phase of volcanism began with the eruption of the Taupo-Rotorua ignimbrites (Grindley and Harrington, 1961; Thompson and others, 1966). Measurements of K/A (Stipp, in press) and remnant magnetization (Cox, 1969) indicate that the Taupo-Rotorua ignimbrites range in age from 0.8 to 0.2 million years B.P. Ninkovich (1968) has dated by paleomagnetic methods five rhyolitic ash layers in deepsea cores east of New Zealand. The ashes have similar ages to the Taupo-Rotorua ignimbrites. No ashes older than 0.8 million years are found in the arcs even though some cores penetrated sediments as old as 3 million years B.P. This data strongly suggests that the most recent phase of volcanism began within the last million years. The late Tertiary Kaikoura orogeny which is responsible for most of the relief of New Zealand, excepting volcanic features, began about middle-Miocene time.

Hays and Ninkovich (1970) in a study of ash layers in deep-sea cores south of the Aleutians found that the oldest of a series of ashes occurred at about 1.8 million years B.P. From a calculation of ship rates they concluded that the most recent phase of underthrusting must have begun 10-12 m.y. B.P., in order to have the underthrust lithosphere reach a depth of greater than 100 kilometers by 2 million years B.P.

\section{Japan}

Minato (1965) in his extensive treatise on the geology of the Japanese Islands has summarized the Neogene history of Japan. The reader is referred to Minato's (1965) monograph for the details of this history, but the important aspects are presented here. Table 4 gives the stratigraphic subdivision of the Japanese Neogene.

Although the history of various parts of the islands differ, the general pattern which applies to many localities including northeast Honshu is as follows. The Nishioga and Daishima stages were characterized by general emergence at the islands and widespread andesitic and rhyolitic volcanic activity. This phase of volcanism was most violent in the Daisima and the subsequent Nishikurosawa stages.

The following Onnagawa and Funakawa stages by contrast are characterized by general subsidence during which the sea attained its maximum transgression in the Neogene (Figure 9; Saito, 1963). Not since the
Cretaceous had so much of the Japanese Islands been covered by the sea. These stages are also characterized by a marked reduction of explosive volcanism over the previous and subsequent Neogene stages. Some igneous activity did occur but it was limited to extrusive basalt and dolerites and intruded diorites and quartz porphyries. The Kitaura Stage is characterized by a new uplift phase and renewed andesitic and dacitic volcanic activity. Large volumes of ignimbrites were extruded during this stage. Andesitic and rhyolitic explosive volcanism continued through the later Pliocene and Quaternary stages with some indication of increased intensity in the Quaternary.

We see then in the Japanese Islands a distinct change in the tectonic pattern occurring in the middle Miocene about the same time as the plate motion change in the Pacific. We would interpret the intensive volcanism of the Nishioga through Nishikurosawa stages as a product of underthrusting associated with the spreading regime prior to 10 million years B.P. The subsidence and general lack of explosive volcanic activity during the Onnagawa and Funnakawa stages occurred about the time of plate re-orientation and the proposed development of a new underthrust slab of lithosphere. The renewed uplift and volcanic activity of the Kitaura and subsequent stages is related to the present regime of plate motion.

\section{North Eastern Pacific and Western United States}

McKenzie and Morgan (1969) and Atwater (1970) in detailed studies of the Cenozoic interactions between the Pacific plate west of North America, associated smaller plates, and the North American plate suggest a continuous evolution from a continent with a marginal trench to a gradually extending transform fault connecting two ridge crests similar to the present configuration. This model assumes no change in the absolute motion of the Pacific plate during at least the last 20 to 30 million years. This model, however, does not explain the change in trend of anomalies since Anomaly 5 on the Juan de Fuca-Gorda Ridge or near the mouth of the Gulf of California. We suggest that the change in absolute motion of the Pacific plate produced changes in the relative motion between the Pacific plate and adjacent plates. These relative motion changes would not necessarily be simultaneous. Our model would suggest that the establishment of the San Andreas fault zone and the initiation of the openof the Gulf of California were synchronous and were a product of these changes in relative motion between the Pacific plate and the North American plate.

\section{Possible Causes of Mid-Miocene Changes of Plate Motion}

Two possible causes of altered plate motions can be readily imagined. First, a change in the interior of the 
TABLE 4

Japanese Stratigraphic Stages

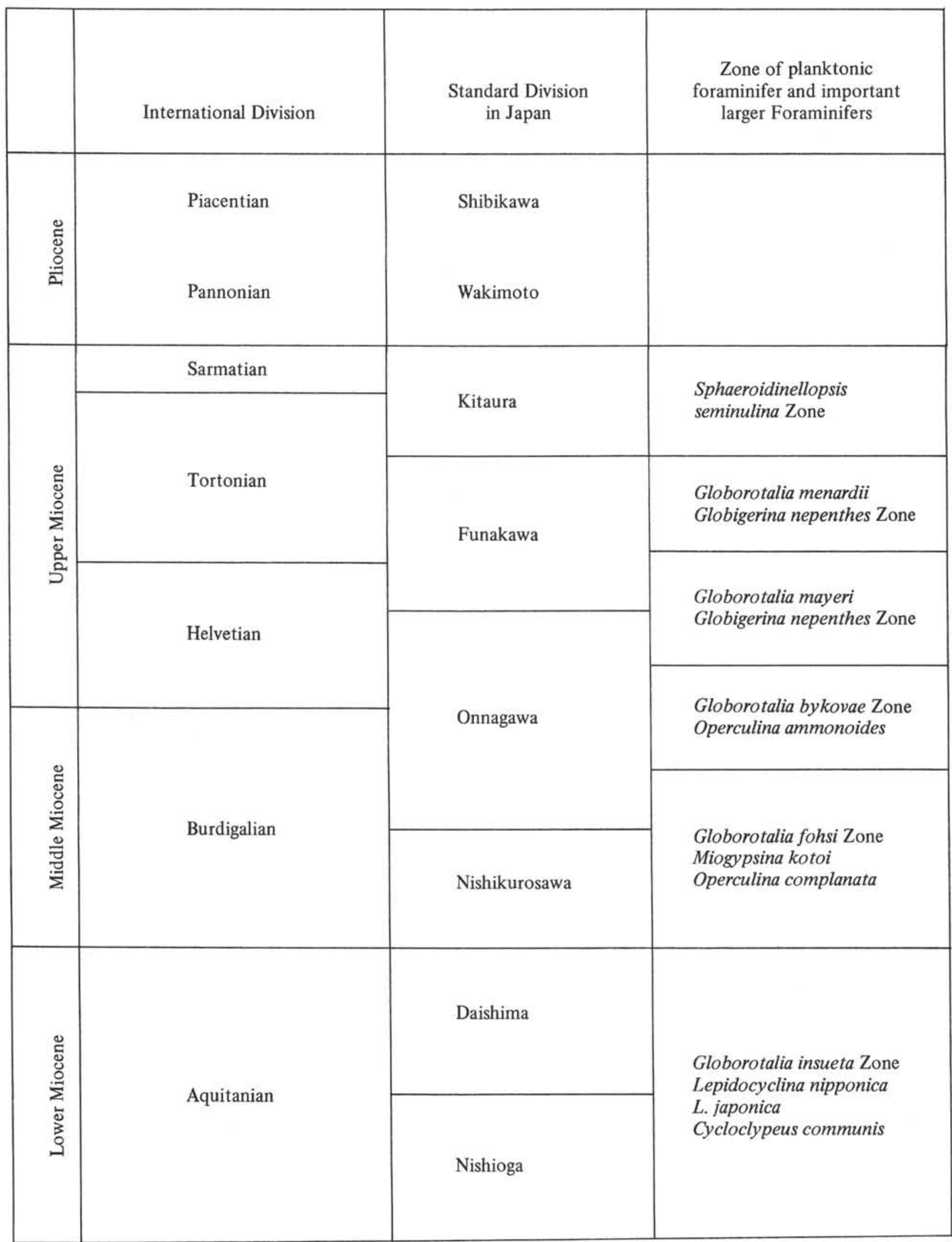



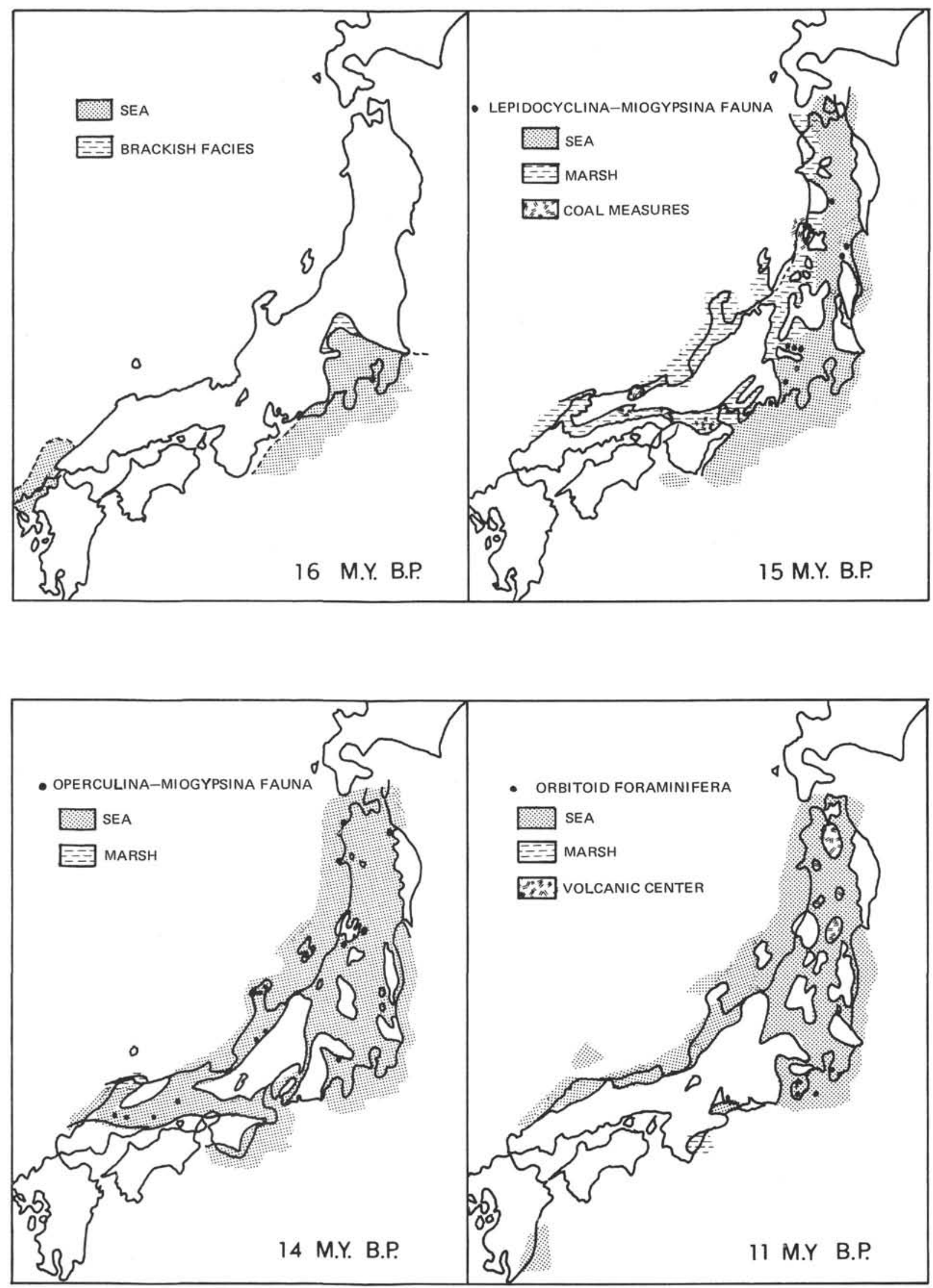

Figure 9. Middle Miocene subsidence in Japan after Saito, 1963. 
earth that effects the driving force, such as, a change in direction or rate of mantle flow. It is unlikely that such changes would occur rapidly. A second possibility is a change in the pattern of interaction of the lithospheric plates. LePichon (1968) has referred to such a mechanism suggesting that plate motion is stopped by the descending lithosphere encountering resistance in the mesosphere.

It goes without saying that the breaking up of continents, such as that occurring with the opening of the South Atlantic, would cause changes in the pattern of spreading. LePichon (1968) pointed out that the Indian subcontinent arrived in close proximity to Asia in the Miocene. The major orogeny in the Himalays also dates from this time. Kummel (1961) states that the first orogenic phase of the formation of the Himalayan mountains began in late Eocene, however, the "...most intense orogenic phase in the Cenozoic history of the Himalays came in the Middle Miocene. This phase was marked by many great thrust faults and severe deformation of the Tethyan formations and by intrusion of great masses of granite into the axial region of the main Himalays."

We appeal to the collison of India with Eurasia as the event that caused the rearrangement of plate motion in the Miocene and initiated the present spreading regime. The rearrangement of stresses and plate motions initiated a new phase of underthrusting and a new orogenic cycle around the margins of the Pacific.

\section{SEDIMENTARY PROBLEMS}

A more detailed discussion of the sediments is given by Cook in Chapter 22 of this volume. We will here concern ourselves with the general aspects of the sediments recovered, the nature of the basal sediments, and the cyclic nature of the sediments encountered.

In general, all the sediments we recovered are high in biogenic components both siliceous (Radiolaria, silicoflagellates and diatoms) and calcareous (coccoliths and foraminifera). The highest concentrations of calcium carbonate occur in the Oligocene and lower Miocene sediments recovered from our western Sites 77 through 80 . In general, detrital components increase from west to east and this is accompanied by generally increasing accumulation rates (Figure 10; Table 4).

The sediments we recovered have been divided into four oceanic formations (Figure 10). These oceanic formations are defined primarily on the basis of color and are given detailed treatment in Chapter 22 of this volume.

The basal formation at most of our sites is the Line Islands Oceanic Formation which is characterized by unusually high concentrations of amorphous metallic oxides, particularly iron and manganese (Table 5; Cook, 1971). Sediments of this formation were recovered on Leg 9 at Sites 77, 78, and 80 through 83, and on Leg 8 at Sites 69 through 74 (Tracey et al., 1971). Similar basal sediments were recovered on Leg 5 (von der Borch and Rex, 1970) suggesting that this formation is widely distributed in the eastern Pacific. The sediments of this formation consist of laminated nannofossil-foraminiferal-radiolarian chalk rich in microscopic and colloidal X-ray amorphous metallic oxides and trace metals $\left(\mathrm{Fe}_{2} \mathrm{O}_{3}, \mathrm{MnO}, \mathrm{So}, \mathrm{Cu}, \mathrm{Ni}, \mathrm{Zn}\right)$. The amorphous iron and manganese is sometimes most concentrated in the lower part of the formation (as at Site 77) decreasing upward and becoming transitional with the overlying sediments. The thickness of this formation varies from about 10 to 25 meters. Radiolaria are absent in the basal parts of the formation and, although present in the upper parts, the assemblage is depauperate suggesting selective solution. Von der Borch and Rex (1970), when describing the amorphous iron-manganese-rich basal sediments cored on Leg 5, noted their similarity to the sediments with high concentrations of metallic oxide precipitates cored on the crest of the oceanic ridge system in areas of high heat flow (Bostrom and Peterson, 1966; Bostrom et al., 1969; Bostrom and Peterson, 1969). Bostrom and Peterson (1966) suggested that the origin of these metallic oxide precipitates was from hydrothermal emanations at the ridge crest. They predicted that sea floor spreading would carry such deposits laterally from the ridge crests, and iron-manganese-rich deposits should be found as the basal sediments over large areas of the ocean basins. Von der Borch and Rex (1970), following this reasoning, interpreted the ironmanganese-rich basal deposits cored on Leg 5 to be the result of such a process. Perhaps the best interpretation of our Line Islands Oceanic Formation is that it has a similar origin. Another possibility exists for at least some occurrences of the Line Islands Oceanic Formation.

At seven of the nine sites we occupied the drilling was terminated in basalt and basalt was recovered. There is strong evidence at all these sites that the basalt is intrusive. The overlying sediments are baked and sometimes brecciated, and sediment xenoliths occur in the basalt. Either the basalts intruded the Line Islands Oceanic Formation after the Line Islands formed by magmatic activity at the ridge crest, or the igneous activity associated with the intrusion of the basalts altered the overlying sediments forming the Line Islands Oceanic Formation. The latter interpretation is not considered likely, since as pointed out by Cook (Chapter 22, of this volume) the metallic oxides occur in laminations of differing concentrations. This strongly suggests that the metallic oxides are syngenetic with the calcareous chalk in which they occur. If the basalts were intruded at or near the ridge crest then the two 
TABLE 5

Atomic Absorption Analyses of the Line Islands Oceanic Formation, Leg 9, DSDP

\begin{tabular}{|c|c|c|c|c|c|c|c|c|c|c|c|c|c|c|c|c|}
\hline \multirow[b]{2}{*}{ Site } & \multirow{2}{*}{$\begin{array}{l}\text { Sample No. } \\
\text { Hole-Core-Section, } \\
\mathrm{cm} \text { from top of sec. }\end{array}$} & \multicolumn{6}{|c|}{$\%$ oxide of element } & \multicolumn{9}{|c|}{ PPM of element } \\
\hline & & $\mathrm{Na}_{2} \mathrm{O}$ & $\mathrm{K}_{2} \mathrm{O}$ & $\mathrm{MgO}$ & $\mathrm{CaO}$ & $\mathrm{Al}_{2} \mathrm{O}_{3}$ & $\mathrm{Fe}_{2} \mathrm{O}_{3}$ & $\mathrm{MnO}$ & $\mathrm{P}_{2} \mathrm{O}_{5}$ & $\mathrm{Ba}$ & $\mathrm{Co}$ & $\mathrm{Cu}$ & $\mathrm{Ni}$ & $\mathrm{Sr}$ & $\mathrm{Zn}$ & V \\
\hline \multirow[t]{6}{*}{77} & $77 \mathrm{~B}-52-1,80-81$ & 0.26 & 0.40 & 1.01 & 13.58 & 0.84 & 1.93 & 0.41 & 0.08 & 1500 & 0 & 580 & 0 & 370 & 140 & 0 \\
\hline & $77 \mathrm{~B}-52-1,100-102$ & 0.20 & 0.44 & 2.45 & 40.89 & 0.93 & 2.80 & 0.60 & 0.07 & 2000 & 0 & 280 & 90 & 510 & 140 & 0 \\
\hline & 77B-52-1, 139-141 & 0.33 & 1.69 & 4.88 & 9.87 & 4.08 & 17.73 & 4.28 & 0.12 & 0 & 680 & 650 & 390 & 510 & 360 & 200 \\
\hline & 77B-52-2, 60-62 & 0.41 & 1.45 & 4.69 & 8.06 & 2.66 & 22.27 & 6.02 & 0.09 & 0 & 780 & 0 & 450 & 520 & 420 & 200 \\
\hline & $77 \mathrm{~B}-52-2,100-102$ & 0.24 & 0.75 & 3.11 & 25.71 & 1.63 & 11.39 & 2.48 & 0.11 & 3900 & 0 & 550 & 160 & 880 & 320 & 0 \\
\hline & 77B-53-1, 97-98 & 0.18 & 0.53 & 2.42 & 32.35 & 0.97 & 11.03 & 1.61 & 0.11 & 1800 & 0 & 530 & 120 & 880 & 260 & 0 \\
\hline 79 & $79-16-3,80-82$ & 0.00 & 0.06 & 0.66 & 47.48 & 0.18 & 1.37 & 0.45 & 0.09 & 0 & 0 & 190 & 0 & 920 & 90 & 0 \\
\hline 80 & $80-5-3,80-82$ & 0.07 & 0.23 & 1.46 & 47.20 & 0.47 & 4.99 & 1.67 & 0.11 & 0 & 0 & 330 & 0 & 750 & 130 & 0 \\
\hline \multirow[t]{4}{*}{81} & $81-6-3,5-7$ & 0.14 & 0.21 & 5.72 & 37.81 & 0.39 & 4.88 & 0.97 & 0.05 & 0 & 0 & 10 & 160 & 380 & 140 & 0 \\
\hline & $81-6-3,140-142$ & 0.12 & 0.08 & 2.92 & 42.62 & 0.12 & 2.99 & 0.81 & 0.08 & 600 & 0 & 450 & 50 & 700 & 130 & 0 \\
\hline & $81-7-1,62-64$ & 0.63 & 0.48 & 4.55 & 30.84 & 3.52 & 4.50 & 5.89 & 0.11 & 0 & 480 & 330 & 460 & 590 & 240 & 0 \\
\hline & $81-7-1,74-75$ & 0.48 & 0.35 & 3.72 & 35.87 & 2.57 & 11.49 & 1.76 & 0.10 & 0 & 0 & 330 & 180 & 560 & 200 & 0 \\
\hline \multirow[t]{2}{*}{82} & $82-6-6,100-103$ & 0.22 & 0.55 & 3.65 & 27.50 & 0.91 & 9.49 & 2.83 & 0.13 & 2100 & 480 & 470 & 120 & 580 & 190 & 0 \\
\hline & $82-6-6,150$ & 0.03 & 0.13 & 1.24 & 21.91 & 0.05 & 2.11 & 0.69 & 0.07 & 0 & 0 & 170 & 60 & 400 & 130 & 0 \\
\hline 83 & $83-8-1$ & 0.09 & 0.16 & 3.96 & 33.36 & 1.26 & 5.10 & 1.13 & 0.13 & 0 & 0 & 0 & 160 & 520 & 280 & 0 \\
\hline
\end{tabular}

Note: The analy tical data for $\mathrm{SiO}_{2}$ is not reported, Comparison of results from the analysis of U.S.G.S. standards W-1 and G-2 against published values for these rocks, allow a wide variation which indicates an analytical problem that existed when the samples were run. The difficulty may be attributed to either deterioration of standards to the beginning of the instrumental breakdown which was detected later in the week. This problem does not affect the accuracy of the other data.

$\mathrm{Pb}$ : All samples contain less than 20 ppm. Dr. Fetter, Institute of Geophysical Planetary Physics, University of California, Riverside, performed the analyses (see Appendix in Chapter 22 for analytical procedures). 

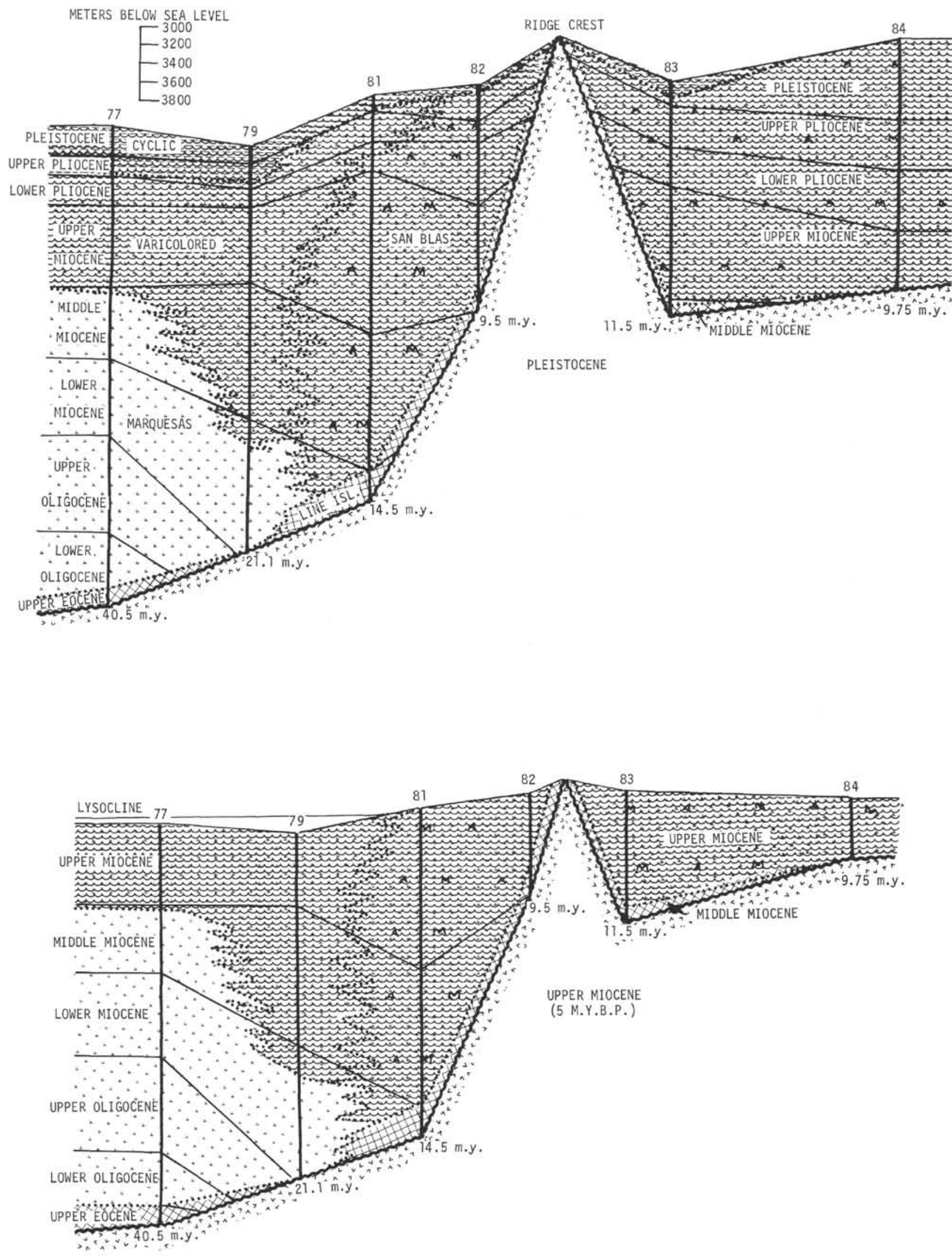

Figure 10. Formations cored by Leg 9 in the eastern equatorial Pacific. 


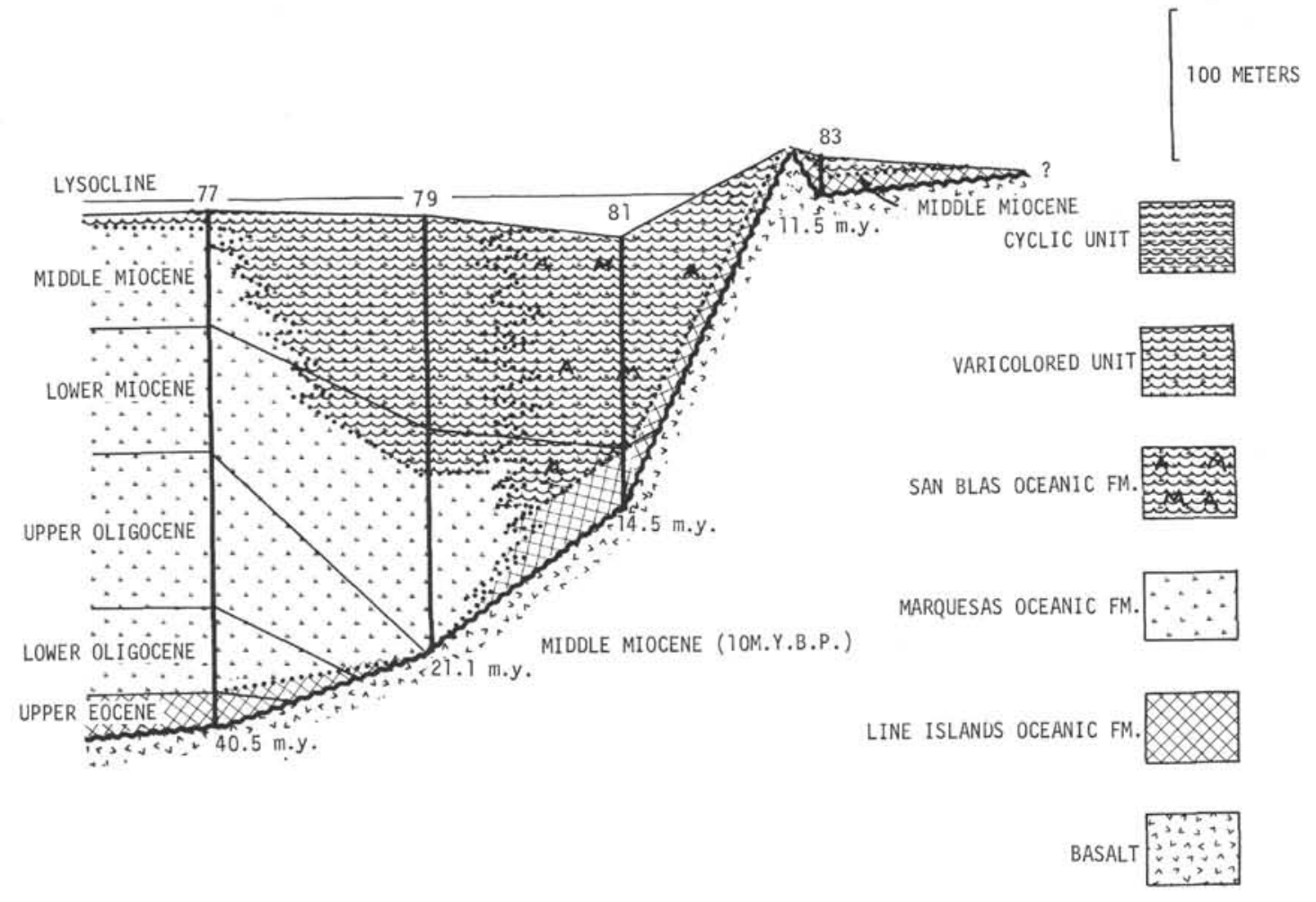

TIME LINE SOLID-FORMATION BOUNDARIES DOTTED

CLIPPERTON OCEANIC FM.
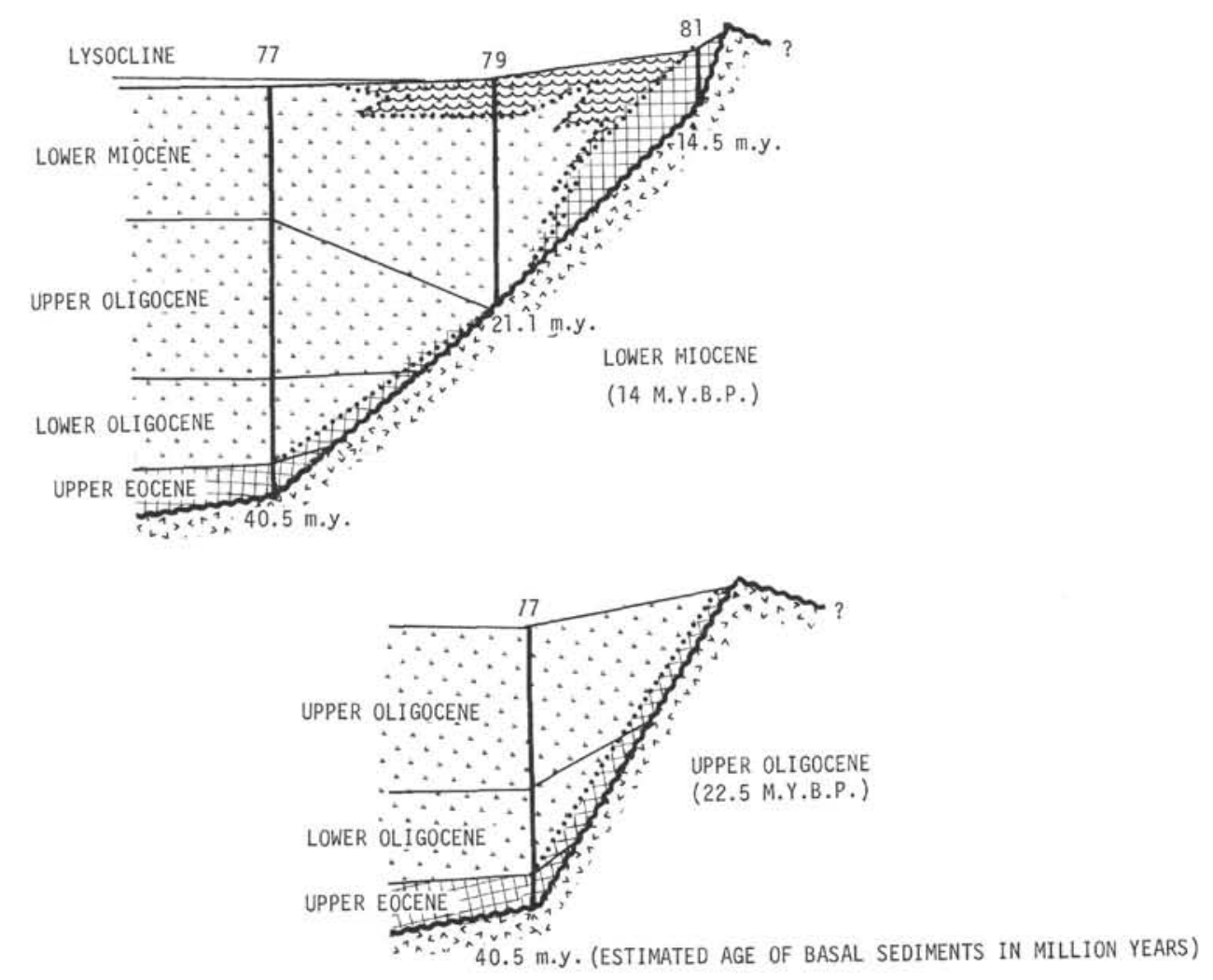

Figure 10. Continued. 
alternative interpretations are for all practical purposes the same. We do not have absolute age determinations for the basalts but the thickness of the overlying Line Islands Oceanic Formation can give a minimum thickness of sediment at the time the intrusion occurred.

The Line Islands Oceanic Formation reaches a maximum thickness of about 25 meters at Site 81, however, since this site was not intensively cored the exact thickness is not known. At all the other sites where this formation was encountered it had a thickness of about 10 meters or less. The average rate of accumulation at Site 81 is about $20 \mathrm{~m} / \mathrm{m}$.y. Assuming that there was at least 25 meters of sediment at this site when the basalt was intruded then this accumulation represents a little over a million years of deposition. This time would have allowed 60 kilometers of spreading to occur if we assume a spreading rate of about $6 \mathrm{~cm} / \mathrm{yr}$. At none of our sites then do we have evidence to indicate that intrusion of basalt occurred beyond the crestal region of the Rise. It seems probable then that the magmatic acitvity that produced the basalts and the Line Islands Oceanic Formation are the same and both probably occurred near the crest of the Rise.

Overlying the Line Islands Oceanic Formation at our western sites (Sites 77, 78, 79 and 80 ) is a thick unit of chalks alternating with radiolarian oozes which we identify as the Marquesas Oceanic Formation, defined by Leg 8 scientists (Sutton et al., 1971). This formation, like the Line Islands Oceanic Formation, is time transgressive ranging in age from Upper Eocene to Middle Miocene at Site 77 but confined to the Middle Miocene at Site 79 (Figure 10). The calcium carbonate content of this formation is very high reaching 95 to 99 per cent $\left(\mathrm{CaCO}_{3}\right)$ throughout much of its thickness. Formianifera and Radiolaria may account for 10 per cent of the sediment; nannofossils compose nearly 90 per cent and detrital clay and other minerals constitute a very small fraction of the sediment.

To the east of Sites 81 through 84 the Marquesas Oceanic Formation is replaced by the light green to grayish-green San Blas Oceanic Formation which contains significantly more continental detritus than the Marquesas Oceanic Formation. A component of this continental detritus is volcanic material. The green to greenish-gray color of the San Blas Oceanic Formation becomes a darker green to the east, and at Site 84 in the Gulf of Panama it can be considered typical of hemipelagic sediments of continental margin areas. The calcium carbonate content of the San Blas Oceanic Formation is significantly lower than the Marquesas Oceanic Formation averaging about 50 per cent $(\mathrm{Ca}$ $\left.\mathrm{CO}_{3}\right)$.

Overlying the Marquesas Oceanic Formation at our western Sites 77 through 80 is the varicolored Clipper- ton Oceanic Formation which was originally described by Sutton et al., (1971). This formation has a generally lower calcium carbonate content (50 to 70 per cent) than the underlying Marquesas Oceanic Formation and a higher radiolarian content. The bedding within this formation is rhythmic with beds high in calcium carbonate alternating with beds high in Radiolaria. This cyclic bedding becomes more pronounced in the upper part of the Clipperton Oceanic Formation and was judged sufficiently distinctive to be separated as a unit (cyclic unit) within the Clipperton Oceanic Formation. The Clipperton Oceanic Formation is one of the most widespread formations encountered stretching from Site 77 to Site 83 (Figure 10).

One of the most characteristic features of the equatorial Pacific sediments is their cyclic nature. This cyclicity is caused by variations in the amount of calcium carbonate present, and although it is most evident in the Clipperton Oceanic Formation it is also present in the highly calcareous Marquesas Oceanic Formation.

Arrhenius (1952) was the first to note the calcium carbonate cycles of the equatorial Pacific, and he interpreted these to be a product of climatic cycles. $\mathrm{He}$ suggested a correlation of those stratigraphic intervals containing relatively high calcium carbonate concentrations with cold periods and those containing relatively low calcium carbonate concentrations with warm intervals. He reasoned that during cold periods the trade winds would be more intense than during warm periods and would stimulate the equatorial current system producing greater upwelling and hence greater productivity at the equatorial divergence. This higher productivity would engender higher calcium carbonate production in the surface waters and a higher rate of sedimentation on the sea floor. The higher rate of accumulation would inhibit solution at the bottom, so increased productivity of carbonate plus reduced solution would work together to produce higher concentrations of carbonate in the sediments during glacial periods. Hays and others (1969) accepted Arrhenius' (1952) interpretation of the cycles and paleomagnetically dated and correlated similar cycles from equatorial Pacific piston cores with climatically induced $\mathrm{O}^{18} / \mathrm{O}^{16}$ and faunal changes in the Caribbean.

The significance of the Leg 9 results is that they clearly show that these cycles are not restricted to the Pliocene and Pleistocene but continue back to the base of the section we cored (Upper Eocene). Those cycles are further discussed by Cook (Chapter 22, this volume).

Whatever the cause of these cycles it has existed through much of the Cenozoic and may well be an 
integral part of the processes of our planet having existed throughout geologic time.

\section{Outcropping Tertiary Sediments}

Riedel and Funnel (1964), and Hays and others (1969) have pointed out the unusual occurrence of outcropping or nearly outcropping Tertiary sediments on the northern flank of the Equatorial Pacific lense (Figure 11). Hays and others (1969) have suggested two possible explanations of these Tertiary outcrops. First, that the equatorial belt of high productivity was no wider in middle and lower Tertiary time than it is now, but that sea floor spreading caused the ocean floor to move west-northwestward moving the sediments that accumulated beneath the equator in mid-Tertiary time out from under the zone of high productivity. Our interpretation of drilling results are in accord with this possibility. A second possibility is that a seaway existed through the Isthmus of Panama in early and middle Tertiary time allowing Atlantic water to flow into the Pacific, broadening and intensifying the equatorial belt of high productivity. Our drilling results and those of Leg 8 (Sutton and others, 1971) indicate that the band of more rapidly accumulating sediments was wider in early and mid-Tertiary time than it is today. This could be caused by either greater productivity due to an open isthmus or a somewhat deeper compensation level in early Tertiary time.

\section{REFERENCES}

Andrews, J. and Hsu, K., Jinghwa, 1970. Note 38-a recommendation to the American Commission on Stratigraphic Nomenclature concerning nomenclatural problems of submarine formations. Bull. Am. Assoc. Petrol. Geol. 54, 1746.

1961. Code of Stratigraphic Nomenclature. Bull. Am. Assoc. Petrol. Geol. 45, 645.

Arrhenius, G., 1952. Sediment cores from the East Pacific. Repts. Swedish Deep-Sea Expedition. 5, 85 p. (Goteborg).

Atwater, T., 1970. Implications of plate tectonics for the Cenozoic tectonic evolution of western North America. Bull. Geol. Soc. Am. 81, 3513.

Atwater, T. and Menard, H. W., 1970. Magnetic lineations in the Northwest Pacific. Earth \& Planetary Sci. Letters. 7, 445.

Benioff, H., 1954. Orogenesis and deep crustal structure - additional evidence from seismology. Bull. Geol. Soc. Am. 65, 385.

Berggren, W. A., 1969. Cenozoic chronostratigraphy, planktonic foraminiferal zonation and the radiometric time scale. Nature. 224, 1072.

Berggren, W. A., Phillips, J. D., Bertels, A. and Wall, D., 1967. Late Pliocene-Pleistocene stratigraphy in deepsea cores from the South-Central North Atlantic. Nature. 216, 253.
Boström, K. and Peterson, M. N. A., 1966. Precipitates from hydrothermal exhalations on the East Pacific Rise. Econ. Geol. 61, 1258.

1969. The origin of aluminum-poor ferromanganoan sediments in areas of high heat flow on the East Pacific Rise. Marine Geol. 7, 427.

Boström, K., Peterson, M. N. A., Joensuu, O. and Fisher, D. E., 1969. Aluminum-poor ferromanganoan sediments on active oceanic ridges. J. Geophys. Res. 74, 3261 .

Brune, J. N., 1968. Seismic moment, seismicity, and rate of slip along major fault zones. J. Geophys. Res. 73, 777 .

Chase, C. G., Menard, H. W., Larson, R. L., Sharman, III, F. G. and Smith, S. M., 1970. History of sea floor spreading west of Baja California. Bull. Geol. Soc. Am. 81, 491.

Cook, H. E., 1971. Iron and manganese rich sediments overlying oceanic basaltic basement, equatorial $\mathrm{Pa}$ cific, Leg 9. D.S.D.P. (Abst). Geol. Soc. Am. Annual Meetings, Washington, D. C.

Cox, A., 1969. Geomagnetic reversals. Science. 163, 237.

Dickinson, W. R. and Hatherton, T., 1967. Science. 157, 801 .

Dickson, G. O., Pitman, W. C. and Heirtzler, J. R., 1968. Magnetic anomalies in the South Atlantic and ocean floor spreading. J. Geophys. Res. 73, 2087.

Dickson, G. O., Ladd, J. W. and Pitman, W. C., III, 1972. The age of the South Atlantic (in press).

Ewing, J. and Ewing, M., 1967. Sediment distribution on the mid-ocean ridges with respect to spreading of the sea floor. Science. 156, 1590.

Ewing, J., Ewing, M., Aitken, T. and Ludwig, W., 1968. North Pacific sediment layers measured by seismic profiling. In The Crust and Upper Mantle of the Pacific Area. L. Knopoff, C. Drake and P. Hart (Eds.). Am. Geophys. Union Mono. 12.

Francheteau, J., Harrison, C. G. A., Sclater, J. G. and Richards, M., 1970. Magnetization of Pacific seamounts: a preliminary polar curve for the northeastern Pacific. J. Geophys. Res. 75, 2035.

Grindley, G. W. and Harrington, H. J., 1961. Late Tertiary and Quaternary volcanicity and structure in New Zealand (abstract). Proc. 9th Pacific Sci. Cong., 1957. 12, 198.

Gutenberg, B. and Richter, C. F., 1954. In Seismicity of the earth and associated phenomena. Princeton (Princeton Univ. Press).

Hamilton, E. L., 1967. Marine geology of abyssal plains in the Gulf of Alaska. J. Geophys. Res. 72, 4189.

Hayes, D. E. and Pitman, W. C., III, 1970. Marine geophysics and sea floor spreading in the PacificAntarctic area: a review. Ant. J. U. S. 5, 70.

Hays, J. D. and Nonkovich, D., 1970. Deep-sea ash chronology. In Geological Investigations of the North Pacific. J. D. Hays (Ed.). Boulder, Colo. (Geol. Soc. Am. Mem. 126). 263. 


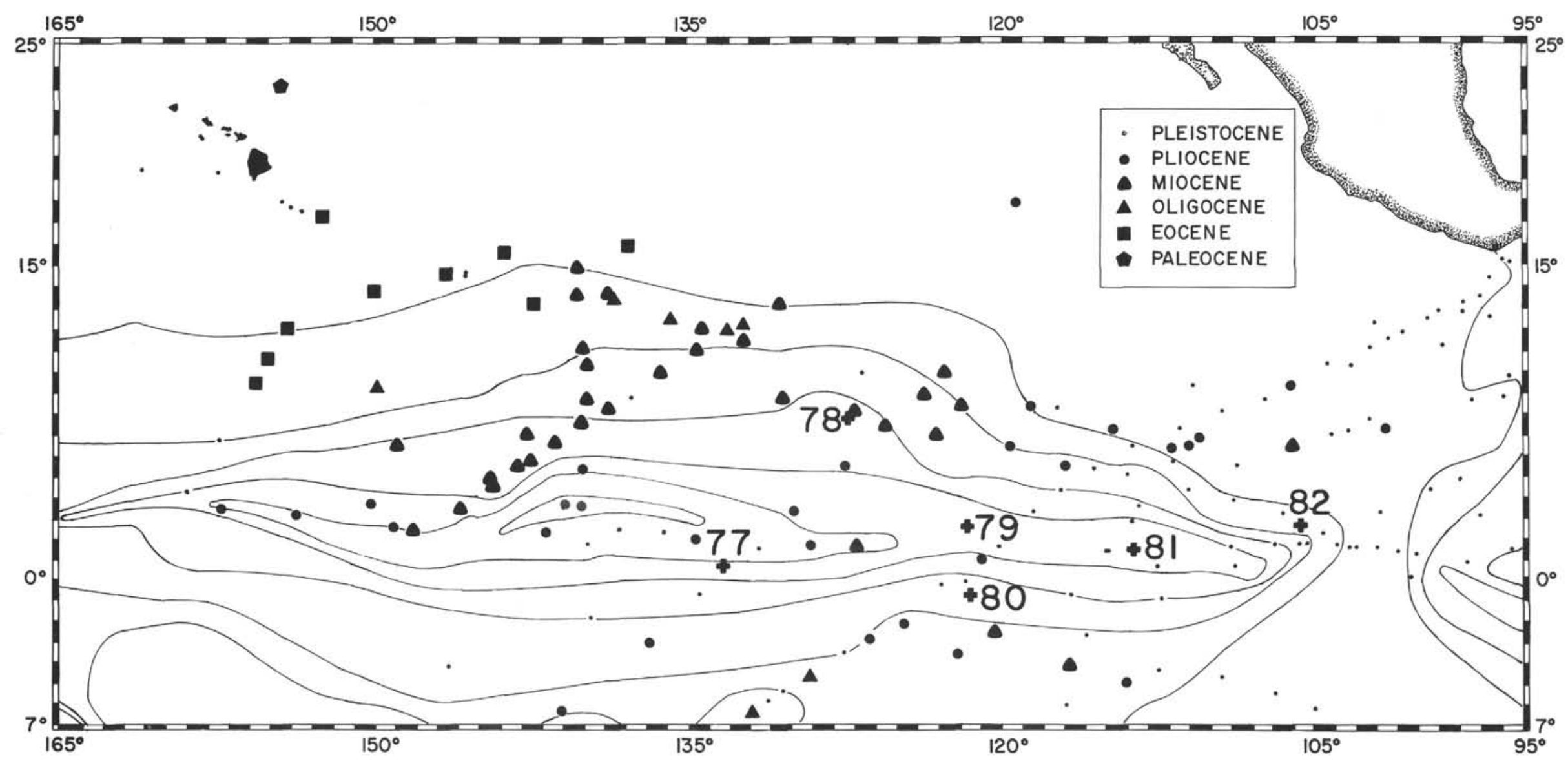

Figure 11. Distribution of Pre-Pleistocene sediments in the eastern equatorial Pacific after Hays et al. (1969). Sediment isopachs after Ewing et al. (1968). 
Hays, J. D., Saito, T., Opdyke, N. and Burckle, L., 1969. Pliocene/Pleistocene sediments of the equatorial Pacific: their paleomagnetic, biostratigraphic and climatic record. Bull. Geol. Soc. Am. 80, 1481.

Herron, E. M., 1971. Crustal plates and sea floor spreading in the southeastern Pacific. Ant. Res. Series. 15, 229. (Am. Geophys. Union).

Herron, E. M., and Hayes, D. E., 1969. A geophysical study of the Chile Ridge. Earth Planet. Sci. Letters. 6,77 .

Honda, H., 1934. On the mechanism of deep earthquakes and the stress in the deep layer of the earth's crust. Geophys. Mag. 8, 179.

Isacks, B. and Molnar, P., 1971. Distribution of stresses in the descending lithosphere from a global survey of focal-mechanism solutions of mantle earthquakes. Rev. Geophys. Space Phys. 9, 103.

Isacks, B., Oliver, J. and Sykes, L. R., 1968. Seismology and the new global tectonics. J. Geophys. Res. 73, 5855 .

Kummel, B., 1961. In History of the Earth. New York (W. H. Freeman and Co.).

LePichon, X., 1968. Sea floor spreading and continental drift. J. Geophys. Res. 73, 3661.

McKenzie, D. and Sclater, J. G. The evolution of the Indian Ocean since the Late Cretaceous. Scripps Inst. Oceano. new series (in press).

McKenzie, D. and Morgan, W., 1969. Evolution of triple junctions. Nature. 224, 125.

McKenzie, D. and Parker, R. L., 1967. The North Pacific, an example of tectonics on a sphere. Nature. $216,1276$.

Maxwell, A. E. et al., 1970. Initial Reports of the Deep Sea Drilling Project, Volume III. Washington. (U. S. Government Printing Office).

Menard, H. W. and Atwater, T. A., 1968b. Changes in direction of sea floor spreading. Nature. 219, 463.

Minato, M., Gorai, M. and Hunahashi, M., 1965. (Eds). In The geologic development of the Japanese Islands. Tokyo. (Tsukji Shokan Co. Ltd.).

Molnar, P. and Oliver, J., 1969. Laternal variations of attenuation in the upper mantle and discontinuities in the lithosphere. J. Geophys. Res. 74, 2648.

Mooney, H. M., 1970. Upper mantle in homogeneity beneath New Zealand: seismic evidence. J. Geophys. Res. 75, 285.

Moore, T. C., 1971, Radiolaria, Leg 8 In Tracy, J. et al., 1971. Initial Reports of the Deep Sea Drilling Project, Volume VIII. Washington (U. S. Government Printing Office).

Morgan, W. J., 1968. Rises, trenches, great faults and crustal blocks. J. Geophys. Res. 73, 1959.
Ninkovich, D., 1968. Pleistocene volcanic eruptions in New Zealand recorded in deep-sea sediments. Earth Planet. Sci. Letters. 4, 89.

Opdyke, N. D. and Foster, J. H., 1970. Paleomagnetism of cores from the North Pacific. In Geological Investigations of the North Pacific. J. D. Hays (Ed.) Boulder (Geol. Soc. Am. Mem. 126). 83.

Pitman, W. C., III, Herron, E. M. and Heirtzler, J. R., 1968. Magnetic anomalies in the Pacific and sea floor spreading. J. Geophys. Res. 73, 2069.

and Talwani, M., 1971. Sea floor spreading in the North Atlantic. Bull. Geol. Soc. Am. (in press).

Riedel, W. R. and Sanfilippo, A., 1970. Radiolaria, Leg 4. Deep Sea Drilling Project. In Badez, R. G. et al., 1970. Initial Reports of the Deep Sea Drilling Project, Volume IV. Washington (U. S. Government Printing Office). 503.

and Funnell, B. M., 1964. Tertiary sediment cores and microfossils. from the Pacific Ocean floor. Geol. Soc. London Quart. J. 120, 305.

Sacks, I. S., 1969. Distribution of absorption of shear waves in South America and its tectonic significance. Carnegie Inst. Wash. Yearbook. 67, 339.

Saito, T., 1963. Planktonic foraminifera from the Neogene Tertiary of Japan. In Fossils. 5, 8.

Sclater, J. G. and Bell, M. L., 1971. The structure and evolution of the East Pacific Rise. Scripps Institute Oceanography. New Series. (in press).

Stipp, J. J., Chappel, J. A. and MacDougall, I., 1967, $\mathrm{K} / \mathrm{AR}$ age estimate of the Pliocene/Pleistocene boundary in New Zealand. Am. J. Sci. 265, 462.

Thompson, B. N., Kermod, L. O. and Ewart, A. (Eds). 1966. In New Zealand Volcanology, Central Volcanic Region. New Zealand (N. Zealand Dept. Sci. and Indus. Research Infor. Ser.) 50, 212 pages.

Tracey, J. I., 1971. Initial Reports of the Deep Sea Drilling Project, Volume VIII. Washington (U. S. Government Printing Office).

van Andel, T. H., Heath, G., Bennett, R., Charleston, S., Cronan, D., Rodolfo, K., Yeats, R., Bukry, D., Dinkelman, M. and Kaneps, A., 1971. Deep Sea Drilling Project Leg 16. Geotimes. 16, 12.

Vine, F. J., 1966. Spreading of the ocean floor: new evidence. Science. 154, 1405.

von der Borch, C. C. and Rex, R. W., 1970. Amorphous iron oxide precipitates in sediments cored during Leg 5, DSDP. In McManus, D. A. et al., 1970. Initial Reports of the Deep Sea Drilling Project. Volume V. Washington (U. S. Government Printing Office). 541.

Wadati, K., 1934. On the activity of deep focus earthquakes in the Japan Island and neighborhoods. Geophys. Mag. 8, 305. 